\author{
RUDIGER DORNBUSCH \\ Massachusetts Institute of Technology
}

PAUL KRUGMAN

Massachusetts Institute of Technology

\title{
Flexible Exchange Rates in the Short Run
}

CONSIDERABLE FLEXIBILITY in exchange rates has marked the seventies. A series of events, starting with the appreciation of the deutsche mark in 1969, and including the realignment in the Smithsonian Agreement in 1971 and a second realignment, have brought the world into a period of controlled flexibility of rates. Flexible rates were the mechanism economists had long advocated for attaining external balance, ${ }^{1}$ but the experience in the last few years has led many to reconsider it.

That reconsideration is stimulated by some surprises in the performance of flexible rates. First among these are the recurrent, large cycles in ex-

Note: We are indebted to Pedro Aspe, Roger Hankin, and Jay Helms for valuable assistance. Helpful comments from Karl Brunner, Jerry A. Hausman, and members of the Brookings panel are gratefully acknowledged. Financial support was provided by a grant from the Ford Foundation.

1. The literature on flexible rates goes back to Milton Friedman, "The Case for Flexible Exchange Rates," in his Essays in Positive Economics (University of Chicago Press, 1953). Subsequent writing includes Egon Sohmen, Flexible Exchange Rates: Theory and Controversy (University of Chicago Press, 1961); Richard E. Caves, "Flexible Exchange Rates," American Economic Review, vol. 53 (May 1963), pp. 120-29; Harry G. Johnson, "The Case for Flexible Exchange Rates, 1969," Federal Reserve Bank of St. Louis, Review, vol. 51 (June 1969), pp. 12-24; Herbert Giersch, "On the Desirable Degree of Flexibility of Exchange Rates," Weltwirtschaftliches Archiv, vol. 109, no. 2 (1973), pp. 191-213; Edward Tower and Thomas D. Willett, The Theory of Optimum Currency Areas and ExchangeRate Flexibility, Special Papers in International Economics 11 (Princeton University, International Finance Section, 1976); and Richard N. Cooper, "Monetary Theory and Policy in an Open Economy," Scandinavian Journal of Economics, vol. 78, no. 2 (1976), pp. 146-63. 
change rates. The dollar-mark rate, for example, fluctuated more than 10 percent in less than six months, though there was no comparable discrepancy in the movement of price levels.

Both the fluctuations in rates and their side effects soon caused governments to adopt exchange-rate targets and to intervene in the market. Governments realized that exchange-rate movements had real effects: they altered relative prices and real incomes and they caused inflation or could serve to reduce inflationary pressure. Exchange-rate targets were also an attractive alternative to the discipline of external balance imposed by a flexible rate, which was far from appropriate in face of the real disturbances of 1973-74. Confronted with a transitory decline in real income, policymakers much preferred using reserves and borrowing to a free adjustment of exchange rates.

The worldwide recession of 1974-76 demonstrated, with the benefit of hindsight, that even under flexible rates there is scope for coordinated stabilization policy. A coordinated expansion in economic activity would have allowed every country to experience some export-led recovery at stable exchange rates.

Against this background, we propose another look at flexible rates and ask how they fit into conventional macroeconomic thinking. The paper seeks primarily to pull together existing knowledge, factual and theoretical. The focus is entirely on the short run.

We are concerned with two related questions: How are exchange rates determined, and what role do they play in a short-run macroeconomic context? The answers are developed in part from theory and in part from empirical evidence. The next major section covers theory, from purchasing power parity and the Keynesian model. The theory of purchasing power parity emphasizes the relation between price levels and the exchange rate but is not a theory of exchange-rate determination and has little to say about the macroeconomic role of exchange rates. Keynesian theory, by contrast, places the exchange rate in the center of macroeconomics. The exchange rate is identified with the relative price of goods and thus is a determinant of the allocation of world spending between domestic and foreign goods. Under conditions of capital mobility there is an important link between international interest rates and the exchange rate.

The Keynesian model serves as a starting point for a realistic model but requires several extensions. Hence, we incorporate the implications of 
exchange-rate expectations, both as part of the adjustment process and as an independent source of macroeconomic disturbances. The model is further extended by a look at the impact of relative prices on the saving rate. It is argued that an exchange-rate movement changes relative prices, or the terms of trade, and therefore changes real income. The change in real income, in turn, may alter saving and spending at an unchanged level of output. The first section ends with a discussion of capital mobility and the suggestion that exchange rates are determined in asset markets. We conclude that asset-market views and balance-of-payments views of exchange-rate determination differ little provided proper emphasis is placed on the capital account in the latter.

The model that emerges emphasizes the link between interest rates and exchange rates, identifies the exchange rate with the terms of trade, and assumes that movements in exchange rates will bring about adjustments in the composition of world demand. The second section presents empirical evidence on some of these issues. First, we find that exchange rates indeed have a strong impact on relative prices. A depreciation will raise import prices relative to export prices, and thus improve a country's competitiveness. For the case of manufactures, a country's share in world exports is significantly determined by its relative price position, but the adjustment takes several years. We also find that, given domestic labor cost, competitors' prices are an important determinant of export prices, thus contradicting the simple Keynesian model. However, this response is only partial, thus leaving some terms-of-trade effect.

In the third section, we find that import prices have an important impact on domestic consumer prices - an effect that is not considered in the simple Keynesian model. Also, that section combines the important features of exchange-rate movements in a short-run macroeconomic context. It draws on the Keynesian model in emphasizing the relation between interest rates and exchange rates and the impact of exchange rates on import prices. It goes beyond the Keynesian model in emphasizing the adverse short-run effects of expansionary monetary policies. The exchangerate depreciation that is induced will only slowly affect the composition of demand; it will immediately raise import prices and thereby consumer prices. It follows that, given flexible rates and capital mobility, countries that seek an expansion in aggregate demand face an adverse inflationunemployment tradeoff. The exchange-rate adjustment speeds up the inflationary impact of monetary expansion. We conclude that under these 
conditions, an individual country will want to use a monetary-fiscal policy mix and that, during a worldwide recession, there is a compelling case for coordinated expansion. These policy considerations are taken up in the fourth and final section.

\section{Theory of Flexible Exchange Rates}

This section provides an overview of the main approaches to flexible exchange rates and lays out the elements of an integrated approach. Traditionally, there have been three quite different views of the role and determination of exchange rates. A monetary approach developed in the wake of the experience after World War I holds that domestic monetary upheaval will be reflected in external depreciation. A second strand of analysis, again originating in the twenties, emphasizes relations between relative price levels and the exchange rate-the famous doctrine of purchasing power parity (PPP). Finally, Keynesian macroeconomics of the open economy under flexible rates was developed in the late forties and elaborated in the sixties and stresses the interaction of output and exchange-rate determination.

\section{PRICES AND EXCHANGE RATES}

Under the skin of any international economist lies a deep-seated belief in some variant of the PPP theory of the exchange rate. ${ }^{2}$ According to the law of one price, a commodity should sell for the same price (freight and duties apart) in various locations. An exchange rate that leaves an international price discrepancy will soon lead to arbitrage and thereby to an adjustment in prices or the exchange rate or both. Given enough time, therefore, the domestic prices of internationally traded goods will correspond to world prices converted at the going exchange rate.

Even if the arbitrage of traded-goods prices is generally accepted, a number of substantive issues remain. Does spatial arbitrage have any further implications for exchange rates, and, specifically, does it imply that

2. The theory and applications of PPP have been extensively reviewed in Lawrence H. Officer, "The Purchasing-Power-Parity Theory of Exchange Rates: A Review Article," International Monetary Fund, Staff Papers, vol. 23 (March 1976), pp. 1-60. 
exchange rates are a function of price levels? Given domestic and foreign price levels, does the doctrine assert that the exchange rate will attain a particular level?

If all goods were traded with no transport costs or duties and with identical weights in the price index, the law of one price would ensure arbitrage of price levels, as well as of individual commodity prices. Obviously, the departures from these assumptions are sufficiently pronounced that this result should not be expected. One alternative is to consider the relative movement of price levels and exchange rates over time. Here it is argued that movements in the exchange rate will offset those in relative prices. This approach will be primarily correct for the case of pure monetary disturbances that leave the relative price structure within a country unaffected, but can be seriously incorrect as a general proposition about actual or equilibrium exchange rates, as Samuelson has emphasized. ${ }^{3}$ In an important contribution, Balassa has pointed out that the growth process is likely to change relative price levels systematically. ${ }^{4}$ With productivity growth concentrated in the traded-goods sector, the resulting increase in labor cost to the service sector will raise home-goods prices and hence the overall price level in the faster-growing country relative to the rest of the world.

The main points of PPP theory can be formalized by reference to the following equation: ${ }^{5}$

$$
\hat{e}=\left(\hat{W}-\hat{W}^{*}\right)+\left(\hat{w}^{*}-\hat{w}\right)+\left(\hat{\theta}-\hat{\theta}^{*}\right) .
$$

Equation 1 summarizes the determinants of exchange rates on the assumption that prices of traded goods are fully arbitraged. Under these conditions the domestic currency will depreciate if domestic nominal

3. Paul A. Samuelson, "Theoretical Notes on Trade Problems," Review of Economics and Statistics, vol. 46 (May 1964), pp. 145-54.

4. Bela Balassa, "The Purchasing-Power Parity Doctrine: A Reappraisal," Journal of Political Economy, vol. 72 (December 1964), pp. 584-96.

5. In equation 1 an asterisk denotes the foreign country, and $e$ is the domesticcurrency prices of foreign exchange. Assuming full arbitrage of traded-goods prices, $P_{T}=e P_{T}^{*}$, or $e=P_{T} / P_{T}^{*}$, which corresponds to the absolute version of PPP. Next we assume a relation between traded-goods prices and the price level in each country, $P_{T}=\theta P$ and $P_{T}^{*}=\theta^{*} P^{*}$ and use the definition of the real wage $w=W / P$ and $w^{*}=$ $W^{*} / P^{*}$ to form the expression $e=P_{T} / P_{T}^{*}=\left(\theta / \theta^{*}\right)\left(W / W^{*}\right)\left(w^{*} / w\right)$. Equation 1 is the logarithmic derivative of this equation. For further comments see Rudiger Dornbusch, "The Theory of Flexible Exchange Rate Regimes and Macroeconomic Policy," Scandinavian Journal of Economics, vol. 78, no. 2 (1976), pp. 255-75. 
wages rise faster than foreign money wages; if foreign real wages rise faster than domestic real wages; or if the ratio of traded-goods prices to home-goods prices rises faster domestically than abroad.

The first term of equation 1 represents the pure inflation effect or monetary effect. With an unchanged real structure the country experiencing the higher rate of wage inflation will have a depreciating exchange rate. The second term shows the impact of real changes. More rapid increases in real wages (stemming from extraordinary productivity growth) are reflected in an appreciation in the currency. The last term in equation 1 concentrates on changes in the relative-price structure. An increase in the relative price of traded goods, given real and money wages, implies a depreciation of the currency.

Equation 1 is a convenient representation of the influences on exchange rates. Even so it is not entirely satisfactory because of two strong assumptions built into the formulation that are not supported by empirical evidence for the short run. First, the only variation in relative prices is that between home goods and traded goods; the terms of trade are constant. Second, the law of one price actually holds.

A more important objection to a formulation such as equation 1 is that it implies a line of causation from wages and the real structure to the exchange rate. Such a view disregards the interaction between exchange rates and prices. PPP is at best an equilibrium relation between exchange rates and prices, not a theory of the exchange rate.

Nonetheless, one would expect a large part of exchange-rate movements to be accounted for by divergent trends in prices $\left(\hat{W}-\hat{W}^{*}\right)$ and in productivity growth $\left(\hat{w}-\hat{w}^{*}\right)$. To put it differently, the proper approach may be to explain the discrepancies from equation 1 rather than express surprise at a tendency for the law of one price to operate.

\section{KEYNESIAN ANALYSIS OF FLEXIBLE RATES}

Work on flexible rates in a macroeconomic perspective goes back to Polak, and Laursen and Metzler, as well as James Meade. ${ }^{6}$ The analysis

6. Jacques J. Polak, "European Exchange Depreciation in the Early Twenties," Econometrica, vol. 11 (April 1943), pp. 151-62; J. E. Meade, The Balance of Payments (Oxford University Press, 1951); and Svend Laursen and Lloyd A. Metzler, "Flexible Exchange Rates and the Theory of Employment," Review of Economics and Statistics, vol. 32 (November 1950), pp. 281-99. 
draws flexible rates into a macroeconomic framework by identifying the exchange rate with the terms of trade, which in turn affect the composition of domestic spending and are a determinant of exports. Given the interest rate and the (fixed) level of domestic prices, a depreciation raises import prices and-assuming appropriate restrictions on elasticities-shifts world demand toward domestic goods and improves the balance of trade.

In the absence of capital flows the exchange rate will adjust to maintain the trade balance in equilibrium. An expansionary domestic policy, for example, would raise income and import spending. The resulting trade deficit would cause a depreciation and switch demand toward domestic goods until the deficit was eliminated. For this simple case, flexible rates make expansionary policies operate exactly as they do in a closed economy. Since the trade balance is maintained in equilibrium by exchangerate adjustment, the economy, in effect, is closed for the purposes of income determination.

The analysis becomes considerably more interesting when it includes capital mobility and interaction between countries in the determination of macroeconomic equilibrium, following the theories of Mundell and Fleming. ${ }^{7}$ The notion of capital mobility is best captured by the extreme assumption that domestic and foreign securities are perfect substitutes. Abstracting from exchange-rate expectations, this implies that domestic and foreign interest rates are the same. That link has very strong implications for monetary and fiscal policy under flexible rates.

The two-country model with perfect capital mobility is depicted in the diagram below. The equations are those for monetary equilibrium in each country (standard LM equations) and for equilibrium conditions in the goods market. In the goods market, prices are fixed in each country's currency and the supply of output is perfectly elastic. The demand for a country's output is equal to that country's expenditure plus the trade surplus or net exports. The trade surplus, in turn, is a function of the exchange rate-the relative price of goods or the terms of trade-as well as of both countries' incomes. The model is completed by the requirement that interest rates be the same in the two countries.

In the diagram the $A A$ schedule depicts the combinations of income

7. See Robert A. Mundell, International Economics (Macmillan, 1968), chaps. 11, 17, and 18, and J. Marcus Fleming, "Domestic Financial Policies Under Fixed and Under Floating Exchange Rates," International Monetary Fund, Staff Papers, vol. 9 (November 1962), pp. 369-79. 


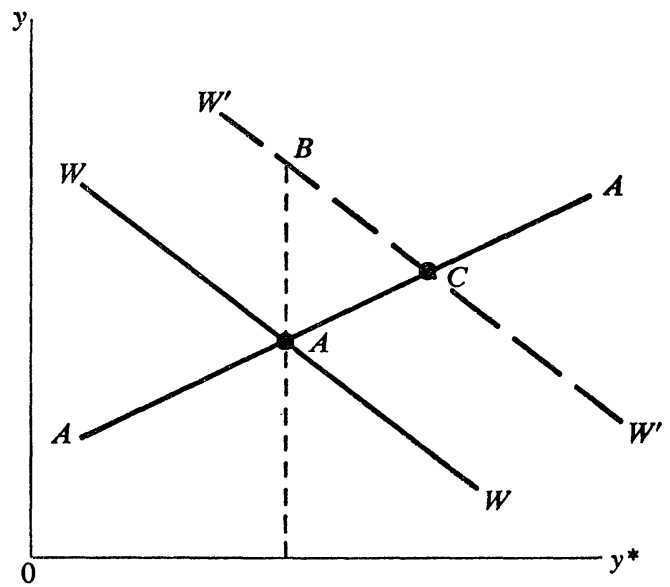

levels that yield monetary equilibrium and equality of interest rates. Given the money supply, an increase in home income will raise equilibrium interest rates. To maintain international equality of interest rates, foreign income would have to rise along with domestic income. The slope of the $A A$ schedule is positive (the essential result) while its magnitude depends on relative income and interest elasticities at home and abroad. ${ }^{8}$

The $W W$ schedule, which expresses equilibrium in the two countries' goods and money markets, is generated by alternative exchange rates, given money supplies and fiscal policy. For any point on the schedule and an assumed depreciation of the domestic currency, the implied increase in the relative price of foreign goods will shift world demand toward domestic output. To meet the resulting excess demand, domestic output will have to rise while foreign output will decline. The magnitude of the

8. The equations corresponding to the schedules are the following. Solving the money-market (LM) equilibrium for interest rates as functions of income and money: $r=\bar{r}(y, M)$ and $r^{*}-\bar{r}^{*}\left(y^{*}, M^{*}\right)$. Along the $A A$ schedule $\bar{r}(y, M)=$ $\bar{r}^{*}\left(y^{*}, M^{*}\right)$, where $M$ and $M^{*}$ are the domestic and foreign money supplies. The $W W$ schedule represents equilibrium in the goods market: $y=A(\bar{r}, y, \gamma)+$ $T\left(y, y^{*}, e\right)$ and $y^{*}=A^{*}\left(\bar{r}^{*}, y^{*}, \gamma^{*}\right)-e T\left(y, y^{*}, e\right)$, where $A$ and $A^{*}$ represent domestic and foreign absorption in terms of the respective countries' goods. The terms $\gamma$ and $\gamma^{*}$ represent fiscal policy, and $T$ is the trade surplus. The $W W$ schedule is generated by considering alternative exchange rates and finding the corresponding equilibrium levels of output. In the neighborhood of the initial equilibrium the trade balance is assumed zero. We assume, without much justification, that import spending is not responsive to the rate of interest. 
income changes depends on marginal propensities and interest elasticities. The schedule is negatively sloped.

A movement up and to the left along the $W W$ schedule corresponds to a progressive depreciation of the home country's currency, or a progressive worsening of the home country's terms of trade. Accordingly, the movement induces a growing trade surplus that supports the expansion in income. The same point can be made so as to emphasize the absorption approach. A movement to the left along $W W$ implies that domestic income and interest rates rise. With a marginal propensity to spend that is less than unity and with spending further dampened by the higher interest rate, income rises relative to spending and thus the home country has an external surplus. Precisely the opposite argument holds for the foreign country.

Initial equilibrium obtains at point $A$. Given money supplies in each country and fiscal policy at point $A$, the exchange rate, the interest rate, and income levels are such that goods and money markets clear in each country. At $A$, interest rates are equalized as required under perfect capital mobility.

Consider now a fiscal expansion at home. At the initial exchange rate the expansion in demand will raise domestic income. Accordingly, the $W W$ schedule shifts up to $W^{\prime} W^{\prime}$. In the short run, the fiscal expansion will raise income at home and raise interest rates relative to those prevailing abroad. The differential in interest rates will tend to induce a capital inflow that causes the home currency to appreciate. This appreciation shifts demand toward foreign output, thus dampening the income expansion at home and spurring an expansion abroad. The process continues until point $C$ is reached. At $C$ the fiscal expansion at home will have caused income and interest rates to rise in both countries. Therefore, under perfect capital mobility, fiscal expansion-or any autonomous expansion in aggregate demand-raises equilibrium income everywhere in the world.

A critical link in the transmission of fiscal expansion to the rest of the world is the appreciation of the expanding country's currency. This may appear paradoxical: clearly, the initial effect of the expansion must be a worsening of that country's trade balance, which might point toward depreciation, not appreciation. The explanation is that the assumption of perfect capital mobility ensures that, with income and interest rates rising, the capital inflow will be potentially infinite and, hence, the capital- 


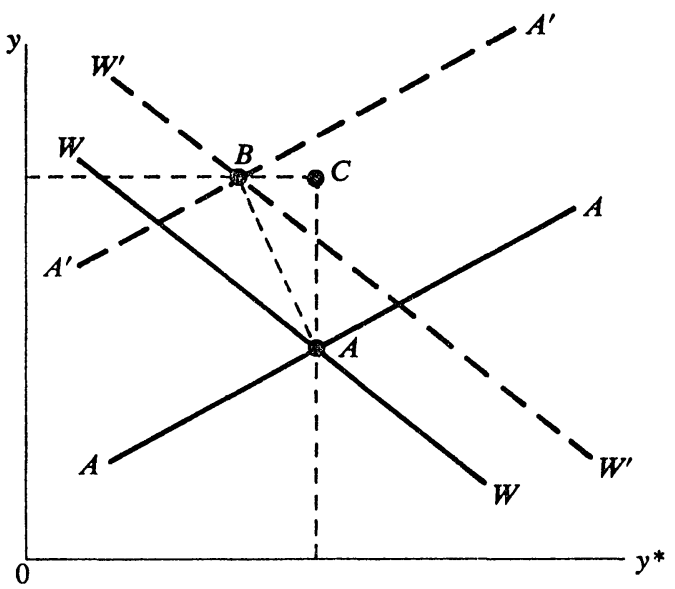

account surplus will dominate any trade deficit and force an appreciation of the currency.

What can be said about the new equilibrium at point $C$ ? The expanding country will have a trade deficit and will experience an actual capital inflow. The argument can be made simply by reference to the absorption approach and consideration of the foreign country. Abroad, income has risen (from $A$ to $C$ ) and has pulled up interest rates. With a foreign propensity to spend that is less than one and with spending further dampened by higher interest rates, foreign income will have risen relative to spending and thus the foreign country will enjoy an improvement in the trade balance and an actual capital outflow. Indeed, the change in the trade balance is the channel through which a fiscal expansion in one country is translated into an income expansion abroad.

One of the very strong predictions of the Mundell-Fleming model concerns a monetary expansion in one country. The model implies that income will rise in the country where the money supply increases and that income will fall abroad. The accompanying diagram is helpful in understanding that adjustment process. The increase in money would lower domestic interest rates and, therefore, generate a potential capital outflow. The resulting currency depreciation shifts demand toward domestic goods and causes an income expansion. The income expansion boosts interest rates somewhat. Abroad, because demand shifts away from foreign 
goods, output declines and so do interest rates. By this process a new equilibrium occurs at point $B$, where interest rates are equalized again at a lower level, domestic income has risen, and foreign income has declined. The home country's currency has depreciated and the trade balance has improved so that there is an actual capital outflow.

Again, the absorption approach helps to explain the trade balance and the direction of actual capital flows. With perfect capital mobility, domestic and foreign securities carry the same yield. Thus capital flows are determined by spending and saving decisions, not by interest rates. At point $B$, interest rates have declined and income has fallen for the foreign country. The declines both of interest rates and of income raise spending relative to income, given a spending propensity of less than one. Accordingly, at point $B$, the foreign country has a trade deficit and therefore is borrowing in the world market. The home country is lending or experiencing a capital outflow.

The second diagram showed that a domestic monetary expansion lowers income abroad. The next question concerns appropriate offsetting policies by the foreign country that would leave foreign income unchanged while attaining the domestic target. What policy combination would produce result $C$ rather than $B$ ? Clearly, a monetary expansion by the home country must be supplemented by both monetary and fiscal expansions abroad. The monetary expansion abroad raises the foreign country's income and lowers the home country's. The fiscal expansion raises income in both. A combination of the two will result in a move from $B$ to $C$.

Two interesting further results emerge in the context of these offsetting policies. First, perhaps surprisingly, it does not matter which country provides the fiscal expansion. If the home country provides it, domestic interest rates will tend to rise, leading to an appreciation of its currency and a shift in demand abroad. The converse will be true if the foreign country provides it. In general, fiscal expansion is shared out to the rest of the world.

Second, and also perhaps surprisingly, the trade-balance effect of the combined policies that expand income in one country while maintaining it in the other involves a shift toward surplus by the expanding country.

From the Mundell-Fleming model we retain the general proposition that foreign monetary or fiscal disturbances are transmitted internationally. Offsetting these disturbances requires active monetary or fiscal policy. While a monetary-fiscal policy mix can maintain the level of out- 
put, it cannot maintain the composition between domestic demand and net exports, nor can it maintain the exchange rate and therefore the terms of trade. There is perhaps nothing surprising about the result that foreign real disturbances-including changes in money-have a domestic effect, but these facts certainly stand in sharp contrast to a popular, unqualified belief that flexible rates insulate a country from external shocks.

\section{EXCHANGE-RATE EXPECTATIONS AND CAPITAL FLOWS}

The Mundell-Fleming approach to macroeconomics under flexible rates emphasizes interdependence and capital mobility. Capital mobility takes on even more significance when we introduce exchange-rate expectations and their impact on macroeconomic activity. ${ }^{9}$ To formalize exchangerate expectations, assume again a world of perfect capital mobility so that net yields on domestic and foreign debt are equalized. Assume, contrary to Mundell-Fleming, that exchange-rate expectations are adaptive, possibly with a disturbance term.

Investors will equate net yields on domestic and foreign assets:

$$
r=r^{*}+\lambda,
$$

where domestic and foreign interest rates are $r$ and $r^{*}$, respectively, and the premium or the expected future exchange rate as a fraction of the spot rate is $\lambda$. Equation 2 states that investors have to be compensated for an anticipated depreciation of domestic currency $(\lambda>0)$ by a commensurately higher interest rate. If expectations are formed adaptively, the expected premium, $\lambda$, is a function of current and past exchange rates $\left(e, e_{-1}, \ldots\right)$ and a disturbance term, $u$ :

$$
\lambda=\lambda\left(e, e_{-1}, \ldots, u\right) .
$$

Incorporating equations 2 and 3 in the Mundell-Fleming model permits consideration of speculative disturbances and the resulting adjustment

9. The role of exchange-rate expectations in a macroeconomic context has been emphasized by Robert A. Mundell, "The Exchange Rate Margins and Economic Policy," in J. Carter Murphy, ed., Money in the International Order (Southern Methodist University Press, 1964); Victor Argy and Michael G. Porter, "The Forward Exchange Market and the Effects of Domestic and External Disturbances Under Alternative Exchange Rate Systems," International Monetary Fund, Staff Papers, vol. 19 (November 1972), pp. 503-32; and William H. Branson, Financial Capital Flows in the U.S. Balance of Payments (Amsterdam: North-Holland, 1968). 


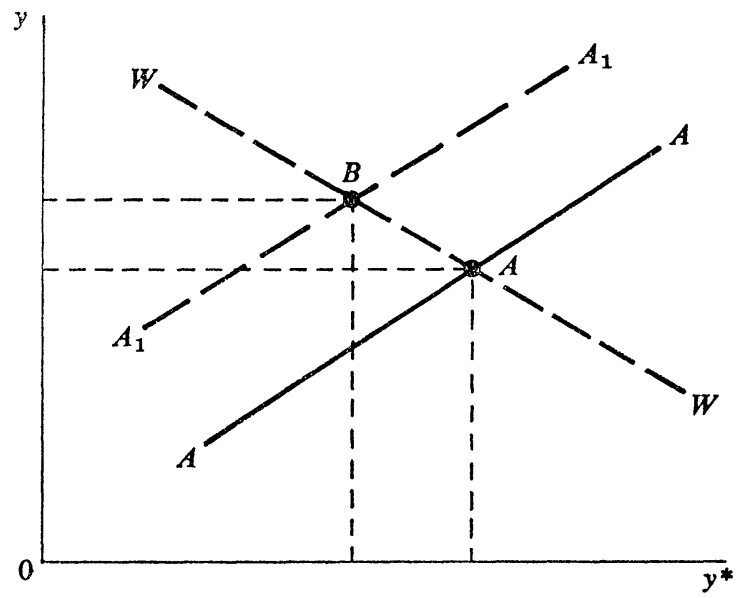

process. Assume for some reason-other than current changes in monetary or fiscal policy - that the expectation of a domestic depreciation develops. At unchanged interest rates a capital loss on domestic assets will be expected and, accordingly, at each level of foreign interest rates, domestic interest rates will have to be correspondingly higher. In the diagram above this is shown by an upward shift of the $A A$ schedule.

A short-run equilibrium is point $B$, where the expectation of a depreciation has caused the currency actually to depreciate. In response, world demand shifts toward the depreciating country's goods and thus raises output there while lowering it abroad. A speculative disturbance, therefore, exerts a direct impact on equilibrium levels of income. The causation runs from exchange-rate expectations to incipient capital flows to actual exchange-rate movements which affect the composition of world spending and therefore equilibrium output levels. For the depreciating country, where interest rates have risen, the higher level of output is sustained by a trade surplus. Abroad, where interest rates have declined, output is lower as are net sales to other countries. There is a net outflow of capital from the country expected to depreciate and that finances the trade surplus.

What happens when the speculative disturbance subsides? The distribution of output over time will return precisely to the initial equilibrium at point $A$. A disturbance, therefore, introduces unnecessary variability in the composition of world output and in relative prices. 
And how can macroeconomic policies be used to offset the speculative disturbance? A policy that stabilizes incomes at point $A$ requires a monetary contraction in the country expected to depreciate or a monetary and fiscal expansion abroad. Simply pegging the exchange rate in the face of an incipient capital outflow amounts to the correct monetary policy. It implies a decline in the domestic quantity of money and thus brings about the requisite increase in interest rates. With higher interest rates, however, aggregate demand is insufficient to support output and thus a fiscal expansion (or some depreciation) is required. The important point is that pegging exchange rates in the face of reversible speculative movements is an efficient way to stabilize income.

The assumed adaptive character of expectations influences the results. Because adaptive expectations are sticky, they could transmit purely monetary disturbances. Assume an increase in foreign wages, prices, and the quantity of money. If the home country's currency appreciated to offset exactly the higher foreign nominal magnitudes, all real variables-in particular, the terms of trade-would remain unchanged and the home country would feel no impact. But with adaptive expectations this full offset does not occur. Future rates will move only slowly and, as a consequence, purely nominal disturbances will be transmitted internationally.

In the short run, the depreciation of the currency that arises from an increase in money and prices abroad induces the expectation of a future appreciation because expectations are formed adaptively. Therefore, the depreciation falls short of the full price increase and nominal interest rates decline in the country where money and prices have risen. With foreign price increases less than offset by the depreciation, demand shifts toward the home country's goods, thus raising domestic income and interest rates. The short-run equilibrium is therefore the same as in the last diagram. Domestic interest rates and income have risen, foreign real income has fallen, and so have foreign interest rates. The foreign currency is expected to appreciate. Only over time, as expectations adjust, is the price increase translated into an equal depreciation and neutrality restored at point $A$.

Clearly, one way a country can intervene to prevent the transmission of foreign disturbances is to peg the exchange rate and share in the foreign nominal expansion by expanding the domestic money supply. Alternatively, once again a tightening of monetary policy together with a fiscal expansion can maintain the initial equilibrium. 
EXCHANGE-RATE EXPECTATIONS, THE TERMS OF TRADE, AND AGGREGATE DEMAND

The Keynesian model, as reviewed in the preceding sections, stresses the identification of the terms of trade with the exchange rate. By raising import prices relative to export and domestic prices, a currency depreciation worsens the terms of trade and in turn shifts demand from the rest of the world toward the depreciating country. A depreciation raises world demand for domestic output and improves the balance of trade.

It has become an accepted fact, however, that in many cases the trade balance worsens over the short term in response to a depreciation, responding favorably only over time. This reversal of direction of the trade effect-which is known as the J-curve and is exemplified by the aftermath of the 1967 U.K. devaluation-is ascribed to a slow adjustment of export prices and physical trade flows in contrast with the rapid increase in import prices.

To understand the operation of the J-curve from a macroeconomic perspective, one must analyze its macroeconomic counterpart. According to the national income identity,

$$
Y \equiv C+I+G+T,
$$

where $C$ is consumption, $I$ is investment, $G$ is government spending, and $T$ denotes net exports; or, rewriting the identity,

$$
T \equiv(S-I)+B,
$$

where $S$ is saving and $B$ denotes the budget surplus, all measured in terms of domestic output.

The equations point out that a worsening of the trade balance must be reflected in a change in the saving-investment balance or in the budget. The extent to which a worsening of the trade balance, such as arises in the short run from a depreciation, is reflected in the various components depends on (i) the origin of the depreciation, (ii) whether the deterioration of the terms of trade is considered temporary or permanent, and (iii) the speed of adjustment in the substitution of domestic goods for imports and the flexibility in intertemporal substitution.

When substitution possibilities are high even in the short run, a transitory exchange-rate movement exerts the maximum effect on the trade 
balance. It gives rise to both intertemporal and intercommodity substitution and thus would clearly improve the trade balance. Saving would rise and investment would decline as a reflection of the intertemporal substitution. Such a high degree of substitutability is, however, not characteristic of the average commodity since otherwise patterns such as the J-curve would not occur. Therefore, in what follows, we assume little scope for intertemporal substitution and a slow rate of intercommodity substitution, even for permanent changes in exchange rates.

Consider first the case of a transitory exchange-rate movement and assume, in the extreme, no substitution. As a consequence, physical trade flows and demand for domestic output will be unaffected. The worsening of the trade balance is "financed" by a reduction in saving. ${ }^{10}$ Therefore, unanticipated, transitory changes in the exchange rate should have quite similar effects on the saving rate and the trade balance: a depreciation should reduce both, while an appreciation should increase both. The impact on inventory investment also tends to reflect the worsened trade balance. An unanticipated increase in import prices will raise the value of inventory accumulation, thus constituting part of the macroeconomic counterpart of the trade deficit.

In contrast, for a permanent deterioration of the terms of trade the response should certainly be an adjustment in the composition and level of spending. As the purchasing power of income, and, therefore, real consumption spending, declines, that reduction will fall on both domestic goods and imports. Furthermore, the substitution effect of a relative-price change will (over time) shift demand away from imports. The demand for domestic goods will rise or fall, and import spending will fall or rise, depending on the elasticity of demand for imports. With the saving rate unchanged, depreciation clearly can exert a deflationary impact unless it is offset by export or investment responses, or by an explicit macroeconomic policy. The impact of the depreciation on investment spending is not predictable. It will depend largely on the behavior of interest rates, aggregate demand, and the relative price of investment goods in terms of output prices and wages. Finally, for exports a quantity adjustment would be expected. A permanent movement in the terms of trade therefore

10. Given unchanged spending on domestic goods and unchanged physical imports at higher prices, total spending must rise, as measured in units of domestic goods or in nominal magnitudes. Measured similarly, saving and the saving rate must decline. 
leaves the ambiguity that inelastic import demand may imply a reduction in spending on domestic goods.

To consider the implications of this analysis for short-run macroeconomic policy, assume that in an attempt to expand aggregate demand the domestic quantity of money is increased. At first that policy reduces domestic interest rates and tends to induce a capital outflow and therefore a depreciation. If expectations about the long-run exchange rate are formed adaptively, the fall of the spot rate is viewed as partially temporary; it thus creates expectations of an appreciation and, therefore, allows a decline in domestic interest rates. Nonetheless, the expected long-run exchange rate will fall somewhat, reducing import demand and raising exports. Assuming sufficient elasticity, import spending will decline and net aggregate demand will rise because of the decline in interest rates. Both sources, therefore, contribute to an expansion in demand for domestic output. But with insufficient elasticity, import spending will rise and the trade balance will fall. Additional effects stem from the excess of the spot-rate fall over the expected long-run fall. Here it is appropriate to assume that the resulting increase in import prices is not offset by reduced imports or increased exports but rather is financed by a reduction in saving.

Presumably, therefore, an expansionary monetary policy will worsen the trade balance by inducing a fall in the spot rate. Demand for domestic output will rise in response to reduced interest rates and may rise or fall in response to the permanent component of the exchange-rate movement. If the adjustment of trade flows and domestic demand to movements in the permanent rate takes time, a reduction in interest rates may actually reduce demand for domestic output in the short run. ${ }^{11}$

The ambiguity that surrounds the short-run impact of exchange-rate movements on demand for domestic output suggests that when an expansion in aggregate demand is desired, a combination of monetary and fiscal policy tools should be applied. Such a policy implies that the exchange rate can remain constant. It avoids the uncertainty (arising from the Jcurve) associated with an attempt to expand domestic output through a net increase in exports.

A further advantage of the policy mix is that it avoids the deterioration in the terms of trade associated with a depreciation, which would depress

11. This possibility has been suggested by Jürg Niehans, "Some Doubts About the Efficacy of Monetary Policy Under Flexible Exchange Rates," Journal of International Economics, vol. 5 (August 1975), pp. 275-81. 
the real income of those already employed. The tradeoff between raising employment and maintaining the real income of those already employed is avoided by a policy that pegs exchange rates in the face of a fiscal expansion.

\section{THE ASSET-MARKET APPROACH TO EXCHANGE-RATE}

DETERMINATION

Recent discussions of the theory of flexible exchange rates have emphasized the role of asset markets, as opposed to the trade balance or the balance of payments, in determining exchange rates in the short run..$^{12}$ But is there, in fact, a significant difference between the stock and flow views?

To start out, the asset-market view relies critically on the assumption of perfect mobility and continuous, instantaneous equilibrium in capital markets. The economy is always in portfolio equilibrium. If domestic and foreign assets are perfect substitutes, the net yields are always and instantaneously equalized. If the assets are imperfect substitutes, a convenient assumption for some purposes, there is nevertheless portfolio equilibrium with respect to the composition of assets at each point in time. ${ }^{13}$ The instantaneous achievement of portfolio balance is understood as perfect capital mobility.

Given this definition of perfect capital mobility, imperfect capital mobility is the case in which portfolio substitution in response to international yield differentials occurs only over time. Such a view gives rise to a "capital-flow function."

Either perfect capital mobility with imperfect substitutability or imperfect mobility allows international interest differentials. In both cases, even a small country can affect the interest rate by changing the relative supplies of assets. In sharp contrast, under the benchmark case of perfect capital mobility and perfect substitutability, nominal interest-rate differ-

12. See, for example, the papers in the Scandinavian Journal of Economics, vol. 78 , no. 2 (1976), as well as the comments by William Branson and the general discussion on Marina v. N. Whitman, "Global Monetarism and the Monetary Approach to the Balance of Payments," BPEA, 3:1975, pp. 537-42, 551-55.

13. On this point, see Lance Girton and Dale W. Henderson, "Financial Capital Movements and Central Bank Behavior in a Two-Country, Short-run Portfolio Balance Model," Journal of Monetary Economics, vol. 2 (January 1976), pp. 33-61, and Rudiger Dornbusch, "Capital Mobility and Portfolio Balance," in Robert Z. Aliber, ed., The Political Economy of Monetary Reform (London: Macmillan), forthcoming. 
entials are possible only because of expectational errors, or, in the long run, because of perfectly anticipated differences in inflation rates consistent with equality of real rates.

In its sharpest formulation, the asset-market view focuses on the benchmark case and moreover assumes that income and nominal asset supplies are predetermined at any point in time. With such a set of assumptions, exchange-rate determination comes down to an equation such as 2 , in which the equilibrium level of the current exchange rate is determined by nominal asset supplies, and the given level of real income and perhaps nonmonetary assets, and is independent of the current account. By assumption, any current-account imbalance can be financed in the world market at prevailing interest rates. To summarize, in the short run, given wealth and asset supplies, the exchange rate is determined in asset markets, and determines the current account; the current account, through its effects on income, prices, and wealth, affects the rate of change of the exchange rate. ${ }^{14}$

Two extensions of the basic conceptual framework significantly modify its force. With the first, which incorporates rational expectations, the current equilibrium level of exchange rates is a function of the entire subsequent path of the economy, including developments in income, prices, and wealth. Although these variables may be predetermined at a point in time, their subsequent evolution affects the current equilibrium level of the exchange rate and thus restores the general-equilibrium determination of exchange rates that was put in question by some variants of the assetmarket view. ${ }^{15}$

14. See Pentti J. K. Kouri, "The Exchange Rate and the Balance of Payments in the Short Run and in the Long Run: A Monetary Approach," Scandinavian Journal of Economics, vol. 78, no. 2 (1976), pp. 280-304; Stanley W. Black, International Money Markets and Flexible Exchange Rates, Studies in International Finance 32 (Princeton University, International Finance Section, 1973); Rudiger Dornbusch, "A Portfolio Balance Model of the Open Economy," Journal of Monetary Economics, vol. 1 (January 1975), pp. 1-20; and Rudiger Dornbusch, "Capital Mobility, Flexible Exchange Rates and Macroeconomic Equilibrium," in E. Claassen and P. Salin, eds., Recent Issues in International Monetary Economics (Amsterdam: North-Holland, 1976; U.S. distributor, American Elsevier).

15. Rudiger Dornbusch, "Expectations and Exchange Rate Dynamics," Journal of Political Economy, vol. 84 (December 1976), pp. 1161-76, and Pentti Kouri, "Foreign Exchange Market Speculation and Stabilization Policy Under Flexible Exchange Rates" (paper presented at the Conference on the Political Economy of Inflation and Unemployment in Open Economics, Athens, Greece, 1976; processed). 
The second extension, imperfect substitutability of assets, provides scope for an independent domestic interest rate on the basis of relative asset supplies rather than exchange-rate expectations. It does not, however, alter the view that exchange-rate determination is independent of the current account. Perhaps the most important corollary of imperfect substitutability is the ability to conduct exchange-rate and interest-rate policies that are independent of one another. With perfect substitutability there is a one-to-one correspondence among interest rates, foreign rates, and the expected premium on foreign exchange. With imperfect substitutability, given the mechanism of, say, adaptive expectations, a central bank can set both an exchange rate and an interest rate. ${ }^{16}$

Models of imperfect substitution remind us that not all exchange-rate movements need be related to monetary disturbances. It is possible to separate an asset-market view from a narrow monetary view of exchangerate determination. For example, if money demand is independent of wealth and expected yields on foreign assets, shifts in asset preferences between domestic and foreign securities will alter exchange rates with no effect whatsoever on the monetary sector.

An alternative to imperfect substitutability is slow adjustment in portfolio composition. In such a view, monetary conditions, along with predetermined income, determine interest rates while the balance of payments determines the exchange rate. This view yields, in the short run, the same predictions as a model of imperfect substitution, and shares with the asset-market approach the emphasis on the relation between interest rates and exchange rates. To appreciate this point consider the balanceof-payments equation

$$
B O P=T(e, y, \ldots)+K\left(r, r^{*}+\lambda\right) ; \lambda=\lambda\left(e, e_{-1} \ldots\right),
$$

where $K$ is the net rate of capital inflow. With income predetermined, monetary conditions determine the interest rate. Balance-of-payments

16. On this argument, see Henry C. Wallich, "Statement," in International Monetary Reform and Exchange Rate Management, Hearings before the Subcommittee on International Trade, Investment and Monetary Policy of the House Committee on Banking, Currency and Housing, and the Subcommittee on International Economics of the Joint Economic Committee, 94:1 (Government Printing Office, 1975), pp. 209-30; and Lance Girton and Dale W. Henderson, "The Effects of Central Bank Intervention in Domestic and Foreign Assets Under Fixed and Flexible Exchange Rates," in D. Logue and others, eds., The Effects of Exchange Rate Adjustment, forthcoming. 
adjustment is brought about by the interaction of actual and expected exchange rates. Expected exchange rates serve the important purpose of inducing speculative capital flows.

A decline of domestic interest rates, as would result from a monetary expansion, tends to induce a capital outflow and a balance-of-payments deficit. The resulting fall of the spot exchange rate will proceed until capital outflows just match the trade surplus. The most interesting case is one in which the trade balance responds to the exchange rate either not at all or perversely. Here the interaction between actual and expected exchange rates stands out most sharply. With the trade balance given or deteriorating in response to the depreciation, the capital account will have to improve if balance-of-payments equilibrium is to be restored. The spot rate will have to fall enough to invite a speculative capital inflow even though domestic interest rates have declined. That is achieved by a depreciation of the currency (on the spot rate) sufficiently large to arouse the expectation of an appreciation equal to or larger than the interest differential. The large drop in the spot rate must therefore lead to a speculative capital inflow that covers the depreciation-induced trade deficit.

Such an interpretation seems to accord with the relevant facts about exchange rates and interest rates and, for practical purposes, cannot be distinguished from the asset-market view. Indeed, its focus on speculative capital flows as the chief link between exchange rates and interest rates precisely duplicates that of the asset view. ${ }^{17}$ The main issue in an appropriate interpretation of the flow view is realistically defining the importance of the capital account and deemphasizing adjustments in the current account as part of the short-run accommodating movement.

Both views of exchange-rate determination suggest why rates fluctuate a good deal in the short run. These fluctuations simply reflect those in short-term interest rates. A rise in domestic interest rates because of a

17. The flow of capital mobility is emphasized by Peter B. Kenen, "Flexible Exchange Rates and National Autonomy," Revista Internazionale di Scienze Economiche e Commerciale [Milan: Bocconi University], vol. 23 (February 1976), pp. 105-27; Polly Allen and Peter B. Kenen, "Portfolio Adjustment in Open Economies: A Comparison of Alternative Specifications," Weltwirtschaftliches Archiv, vol. 112, no. 1 (1976), pp. 33-72; Niehans, "Some Doubts"; and John Williamson, "Another Case of Profitable, Destabilising Speculation," Journal of International Economics, vol. 3 (February 1973), pp. 77-83, and John Williamson, "Exchange-Rate Flexibility and Reserve Use," Scandinavian Journal of Economics, vol. 78, no. 2 (1976), pp. 327-39. 
monetary contraction or an increase in money demand will produce an interest differential that could generate a capital flow. The appreciation of the currency will continue until it is sufficient to cause the anticipation of depreciation at a rate corresponding to the interest differential. The required exchange-rate movement will be larger the higher the elasticity of exchange-rate expectations and the higher the substitutability between domestic and foreign assets. Overshooting of exchange rates thus simply reflects the requirement that expected asset yields be kept in line.

This view is perfectly compatible with a current account that is unresponsive or even responds perversely in the short run. Indeed, the exchange-rate movement will have to be larger the less (or the more perversely) the current-account balance reacts to the exchange rate. The argument that the current account cannot be a determinant of exchange rates because it moves little relative to them misses the point that exchange rates move so much because the current account moves so little.

\section{Exchange Rates, Prices, and Competitiveness}

The preceding review of theory has developed the Keynesian model as a framework for analyzing short-run exchange-rate questions. The purpose of this section is to round out and support that analysis by some empirical evidence on two key issues. First, we explore whether, in fact, exchange-rate movements significantly affect a country's competitive position. The Keynesian model identifies the terms of trade with the exchange rate; it essentially assumes that prices and costs are fixed in terms of supplier currency and that therefore a change in exchange rates raises import prices relative to export prices. We examine this first question from two perspectives. How do exchange-rate movements affect a country's export prices compared with those of its competitors? To what extent do competitors' prices, in turn, feed back onto a country's export pricing? We conclude that exchange rates have an important, persistent effect on relative prices or competitiveness. At the same time, for most countries we study, competitors' prices exert some impact on export prices.

The second key issue is the extent to which trade flows adjust to changes in competitiveness. Here we find that competitiveness significantly affects trade flows, but with a considerable lag. This evidence, therefore, supports the idea of a J-curve. 


\section{EXCHANGE RATES AND RELATIVE PRICES}

Kravis and Lipsey and, more recently, Isard have forcefully made the point that exchange rates affect relative prices. ${ }^{18}$ Their work shows that exchange-rate movements have significant, persistent effects on relative prices even at a quite disaggregated level, and suggests that the law of one price may not hold in the short run.

Clearly, these results, although confirming the Keynesian model, are inconsistent with well-entrenched theoretical reasoning. A reconciliation might be found in differences between commodity groups. Departures from the law of one price are plausible for customer goods; they are less likely for auction goods. ${ }^{19}$ Customer goods are traded in monopolistic competition and their pricing is based on standard cost. Exchange-rate movements will not affect costs significantly in the short run and therefore will leave supply prices unchanged in terms of the supplier's currency. In this way an exchange-rate change will alter the relative price of any two competing customer goods.

Auction goods, by contrast, are traded in organized international markets through a market-clearing pricing process. Here exchange-rate movements should affect supply prices but not realized relative prices. Between auction goods and customer goods lies a gray area in which there is at least some transitory scope for exchange-rate effects on relative prices.

These analytical considerations suggest the desirability of a test for a distinction between customer and auction goods in the relative-price response to exchange-rate movements. But such a test is difficult. At a somewhat aggregative level, indexes for auction goods-say, crude materialsare very sensitive to differences in composition across countries and are dominated by the real disturbances that affect these prices. Thus we con-

18. Irving B. Kravis and Robert E. Lipsey, "Export Prices and the Transmission of Inflation" (University of Pennsylvania, 1976; processed); Kravis and Lipsey, Price Competitiveness in World Trade (Columbia University Press for the National Bureau of Economic Research, 1971); and Peter Isard, "How Far Can We Push the 'Law of One Price'?" International Finance Discussion Papers 84 (Federal Reserve System, 1976; processed).

19. See Arthur M. Okun, "Inflation: Its Mechanics and Welfare Costs," $B P E A$, 2:1975, pp. 351-90; William D. Nordhaus, "Inflation Theory and Policy," American Economic Review, vol. 66 (May 1976), pp. 59-64; Robert J. Gordon, "Alternative Responses of Policy to External Supply Shocks," BPEA, 1:1975, pp. 183-204; and Paul Krugman, "Macroeconomics in an Economy With Both Fixed and Flexible Prices" (Massachusetts Institute of Technology, April 1976; processed). 
centrate in the next sections on the impact of exchange rates on the relative price of manufactured goods.

\section{EXCHANGE RATES AND COMPETITIVENESS}

We now consider the effect of exchange-rate movement on relative prices in a broader time perspective. Figure 1 shows the effective exchange-rate index and a relative-price index for several countries, both with a base $1970=1.00$. The effective exchange rate is formed by using bilateral export weights for a group of eleven industrialized countries. ${ }^{20}$ The relative-price index measures a country's unit export-value index for manufactured goods relative to that of its competitors, measured in the same currency and using bilateral export weights. Thus an increase in the relative-price index implies that a country's export prices have risen relative to those of its competitors and that, accordingly, its competitive position has deteriorated.

The indexes of U.S. effective exchange rates and relative prices depicted in figure 1 show a continuing, though modest, appreciation of the dollar from 1961 until 1971, accompanied by a progressive loss of competitiveness. Through the sixties, the U.S. relative-price position worsened by about 8 percent, corresponding to the "overvaluation" of the dollar that was widely discussed. ${ }^{21}$ Next, through 1973 , the successive depreciations of the dollar brought about a dramatic reversal that by 1974 left the United States in a competitive position better than that at any time in the sixties. In the 1971-73 period the gain in competitiveness was achieved, one for one, by the depreciation of the dollar. After 1973 some erosion of the competitive position arose from an effective appreciation of the

20. The group includes the United States, Canada, Japan, Germany, the Netherlands, Belgium, France, Italy, Sweden, Switzerland, and the United Kingdom.

21. See, for example, Bela Balassa, "Recent Developments in the Competitiveness of American Industry and Prospects for the Future," in Factors Affecting the United States Balance of Payments, Compilation of Studies Prepared for the Subcommittee on International Exchange and Payments of the Joint Economic Committee, 87:2 (GPO, 1962), pp. 27-54; Richard N. Cooper, "Dollar Deficits and Postwar Economic Growth," Review of Economics and Statistics, vol. 46 (May 1964), pp. 15559; Richard N. Cooper, "The Competitive Position of the United States," in Seymour E. Harris, ed., The Dollar in Crisis (Harcourt, Brace \& World, 1961), pp. 137-64; H. S. Houthakker, "Exchange Rate Adjustment," in Factors Affecting the United States Balance of Payments, compilation cited above, pp. 287-304; and Samuelson, "Theoretical Notes on Trade Problems." 


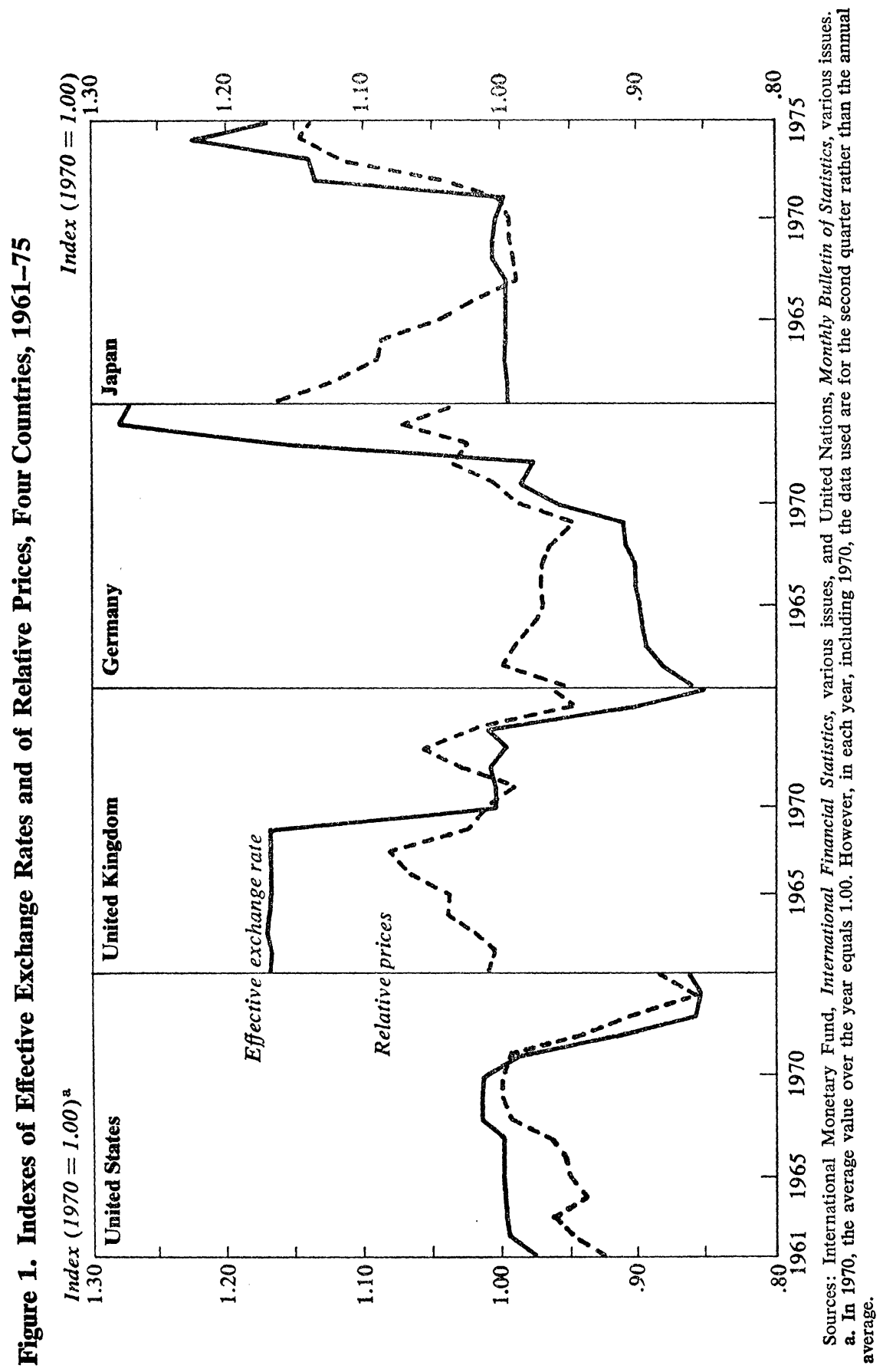


dollar but the effects of that move were dampened by a superior U.S. price performance. The basic conclusion is that for the United States the depreciation, far from matching current differentials in inflation, has, in fact, brought about a significant improvement in competitive position. Moreover, given the low and stable rate of inflation in the United States, that competitive advantage is unlikely to be lost in the next few years unless there is a major appreciation of the dollar.

The case of Japan is precisely the opposite of that of the United States. A strong price performance in the sixties produced a significant gain in competitive position that altogether eroded under the impact of the 197173 adjustment in exchange rates. Again the movement in exchange rates is very closely matched by the change in competitive position.

In Germany and the United Kingdom exchange-rate movements had relatively little impact on the competitive position. These countries were at opposite ends of the domestic-inflation spectrum; their exchange-rate movements largely reflected this difference and had only limited effects on their respective relative-price positions.

\section{COMPETITIVENESS AND TRADE FLOWS}

The next step in providing evidence relevant to the Keynesian model is to determine whether an improvement in a country's competitive position raises its exports and lowers its imports of manufactured goods. Figure 2, which depicts a country's share in industrial countries' real manufacturing exports and the relative-price index, is suggestive in this context. The figure confirms the progressive deterioration in the U.S. competitive position in the sixties and the corresponding decline in the U.S. share in manufacturing exports. Evident from the figure is the lagged character of the adjustment to relative prices, which is the basis for the J-curve. Following the 1971 devaluation, the export share first improved in 1973; by 1975, the cumulative improvement in response to the altered competitive position was significant.

For the United Kingdom the figure shows the recurrent pattern of depreciations that improve competitiveness until that gain is rapidly inflated away, thus bringing on a renewed overvaluation.

To establish evidence for an effective adjustment mechanism, we tested formally whether the relation between the export prices of a country and its competitors is a determinant of its share in world exports of manu- 


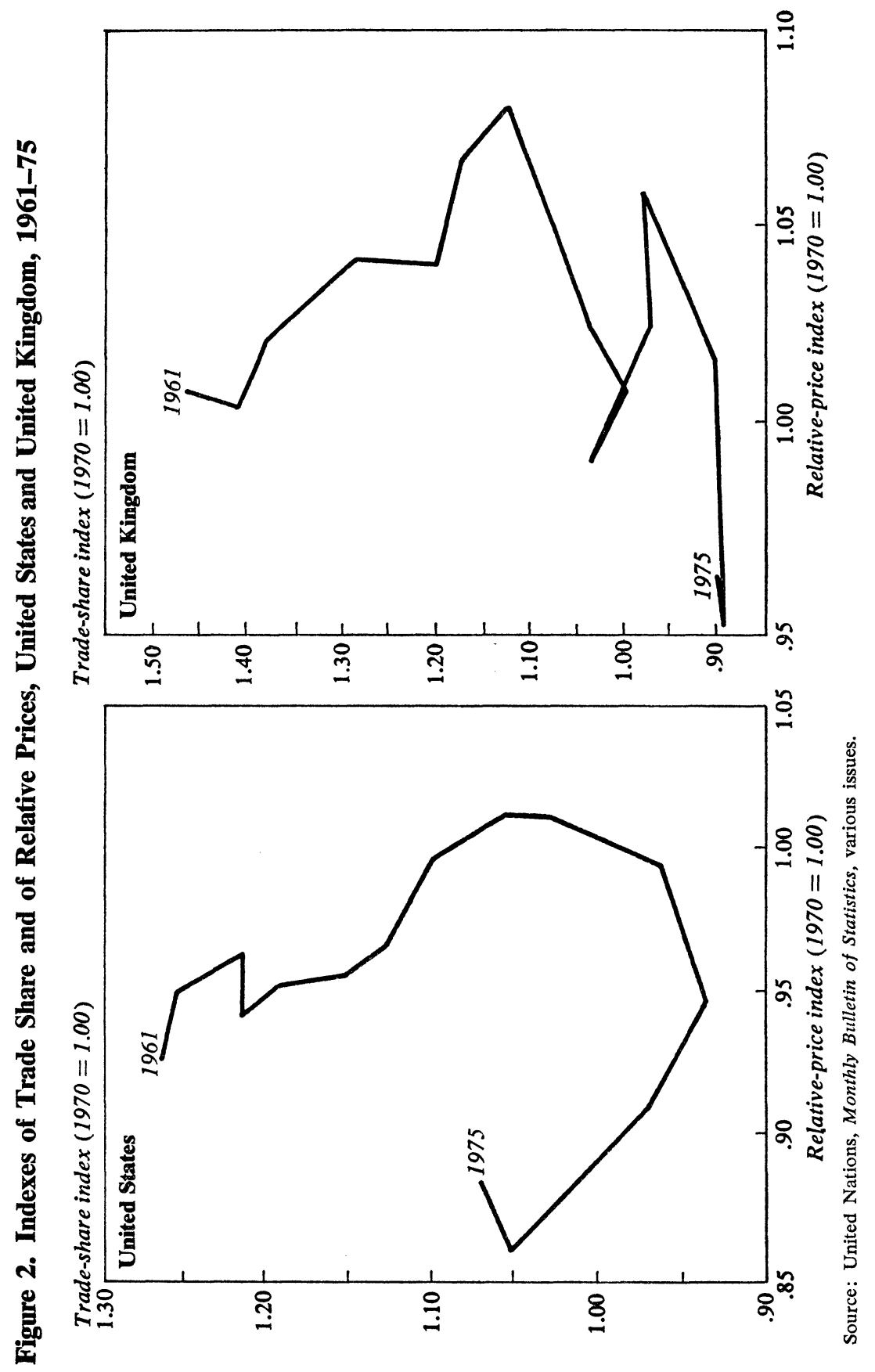


factured goods. For each of the eleven countries-the nine reported in table 1 and Canada and Sweden-we tested an equation with the share as the dependent variable and a time trend and a distributed lag on the relative price as explanatory variables. For seven of the countries, we found a clearly significant price effect. The elasticities of the real export share with respect to the relative price range between one and three.

While the relative price clearly has an important effect, it operates with a considerable lag. With the estimates allowing for lags up to twelve quarters, the mean lag is around four to six quarters for most countries. By comparison, Junz and Rhomberg found much longer lags and an elasticity of 3.88 , which exceeds every one of our estimates. ${ }^{22}$

The estimates for Canada and Sweden show perverse elasticities and are not reported. For Canada the obvious reason is the automotive agreement with the United States that allowed Canadian exports of transport equipment to rise between 1964 and 1969 from 11.4 percent to 39.0 percent of all Canadian manufactured exports. ${ }^{23}$ In the case of Sweden, the explanation is less obvious, although it may be related to the operation of the European Free Trade Association.

Combined with the information about exchange rates and relative prices, the evidence of table 1 makes clear that a sustained depreciation will improve a country's competitive position and that such an improvement will raise exports over time. In the short run, though, elasticities are small; for example, the U.S. elasticity for the first four quarters is only 0.33 , or less than 20 percent of the full adjustment. Such small short-run elasticities can, therefore, give rise to the J-curve. Supplementary evidence on the role of relative prices in determining export performance

22. See Helen B. Junz and Rudolf R. Rhomberg, "Price Competitiveness in Export Trade Among Industrial Countries," American Economic Review, vol. 63 (May 1973), pp. 412-18. See, too, the estimates in H. S. Houthakker and Stephen P. Magee, "Income and Price Elasticities in World Trade," Review of Economics and Statistics, vol. 51 (May 1969), pp. 111-25, as well as the survey by Stephen P. Magee, "Prices, Incomes, and Foreign Trade," in Peter B. Kenen, ed., International Trade and Finance: Frontiers for Research (Cambridge University Press, 1975).

23. Calculated from United Nations, Yearbook of International Trade Statistics, various issues. The automotive agreement applies to cars, trucks, and parts. This is essentially standard international trade classification 73 , which we have taken as the basis for calculating the impact of the automotive agreement. Using annual data for 1962-74 and excluding automotive products we find that the Canadian relative price exerts a significant impact on the export share. The elasticity is 2 with a mean lag of two and one-half years. 


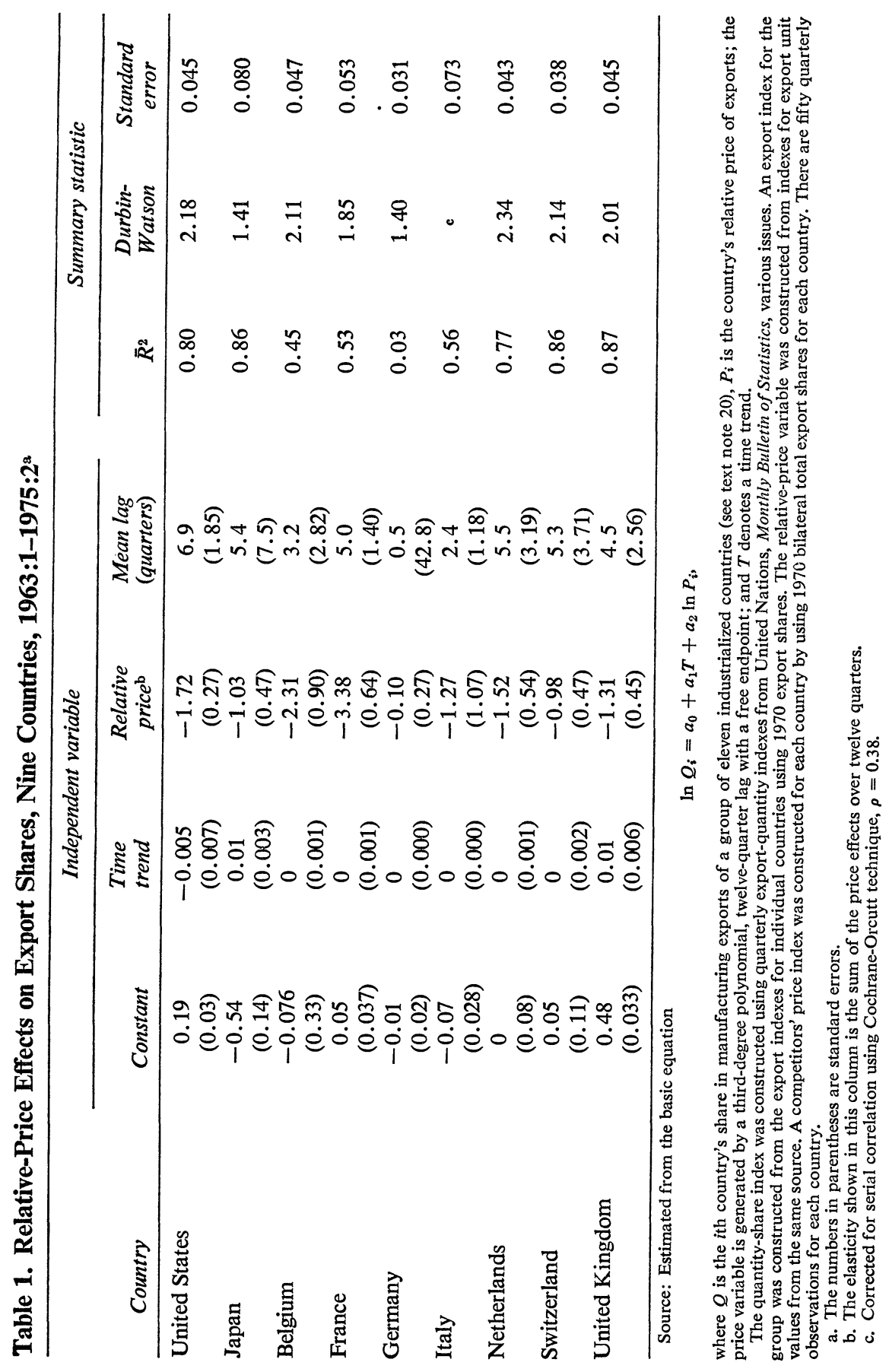


is shown in equation 6 , designed to explain the level of U.S. manufacturing exports $(X)$. World demand $\left(A^{*}\right)$ and the relative price of U.S. exports $\left(P_{U S}\right)$ are significant determinants. ${ }^{24}$

$$
\begin{gathered}
\ln X=-\underset{(1.24)}{1.89}+\underset{(0.31)}{1.42 \ln A^{*}-2.35 \ln P_{U S},} \\
\bar{R}^{2}=0.97 ; \text { Durbin-Watson }=2.35 .
\end{gathered}
$$

where the price variable is again entered as an unrestricted third-degree polynomial with a twelve-quarter distributed lag. (The numbers in parentheses are standard errors.) The price variable is highly significant but again enters with a significant lag. The elasticity within four quarters is only 0.2 and the mean lag is eight quarters.

In summary, then, there is a significant price responsiveness, but adjustment lags are important and run to years, not quarters.

\section{EXPORT PRICING}

Exchange-rate movements lead to changes in the terms of trade that are of considerable duration. Import prices respond rapidly and substantially to exchange rates; but export prices are relatively sticky, behaving as if based primarily on domestic labor cost rather than on competitors' prices.

We investigated the relative roles of labor costs and competitors' prices in export pricing. The results in table 2 use annual data for unit export values for manufactured goods, a variable reflecting standard unit labor costs, and competitors' prices. Although they are not striking and must be considered preliminary, they do give an idea of the process at work. Thus for U.S. manufactured goods labor cost apparently is the determinant of export prices; competitors' prices are unimportant. ${ }^{25}$ By contrast, in

24. In equation 6, U.S. manufacturing exports are a quarterly quantity index seasonally adjusted using a geometric moving average. The world-demand variable is an index of industrial production of U.S. trading partners with weights given by their share in U.S. exports in 1970. The export data come from United Nations, Monthly Bulletin of Statistics, various issues. Industrial production indexes come from International Monetary Fund, International Financial Statistics, various issues. The equation was estimated for the period 1964:1 to 1975:2.

25. The same result is noted by Peter B. Clark, "The Effects of Recent Exchange Rate Changes on the U.S. Trade Balance," in Peter B. Clark and others, eds., The Effects of Exchange Rate Adjustments (Government Printing Office, 1977), forthcoming. 


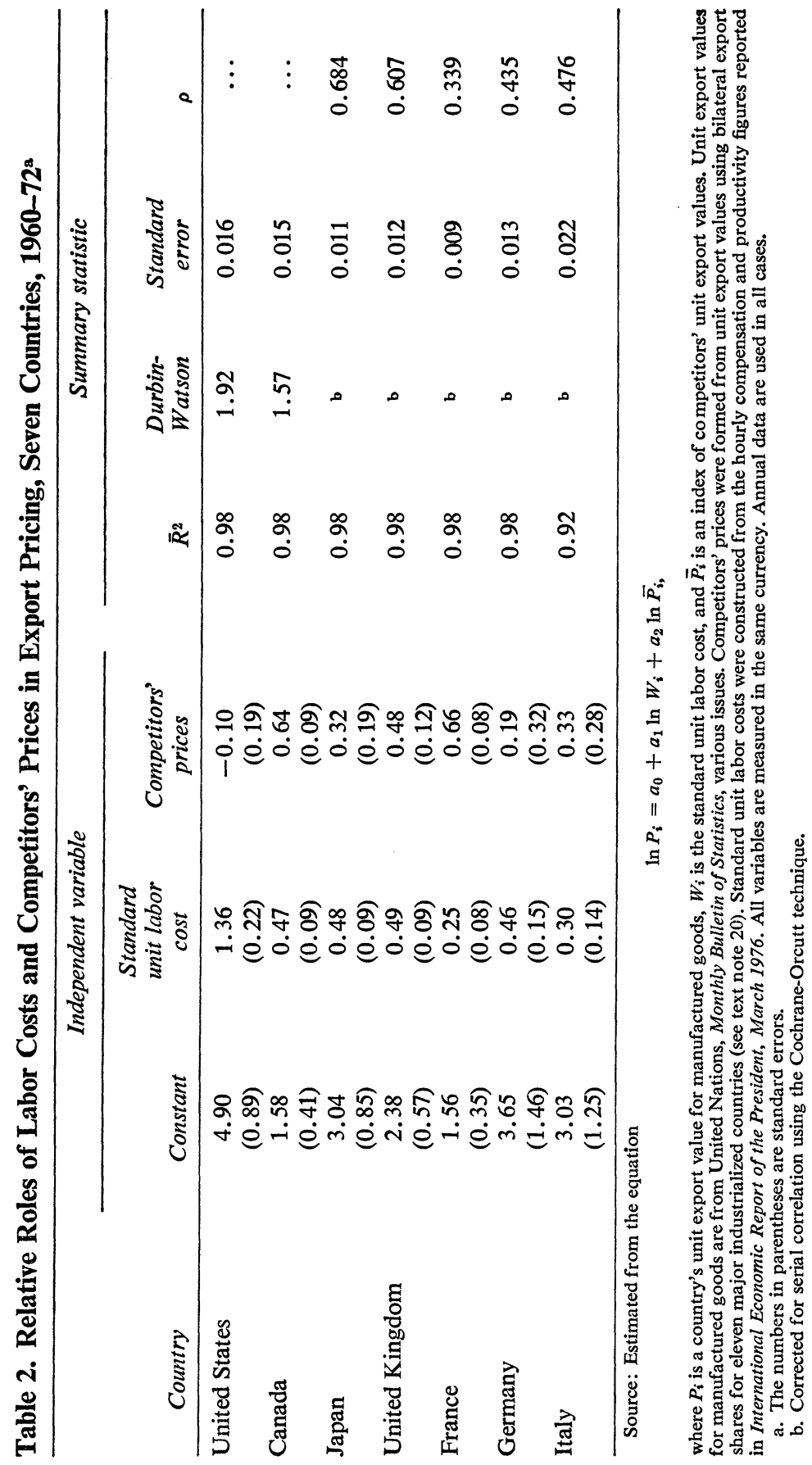


Canada, competitors' prices-and this means to a large extent U.S. prices -have a significant effect, reflected in an elasticity of 0.64 for export prices with respect to competitors' prices. In the United Kingdom and France, similarly, competitors' prices have a significant impact on export unit values.

These results explain how exchange-rate movements affect the shortrun terms of trade. They support the view that export prices remain sensitive to domestic costs and therefore do not simply match competitors' prices. At the same time the results for all countries except the United States point to a considerable responsiveness of export prices to competitors' prices, contrary to the assumption of constant export prices in the Keynesian model.

\section{Exchange Rates and the Domestic Inflationary Process}

Appraisals of flexible rates have noted that exchange-rate movements have, on average, tended to offset divergent movements in national price levels. Countries with high inflation, including Italy and the United Kingdom, have experienced depreciations while those with low inflation rates, such as Germany and Switzerland, have experienced large appreciations. In this context, Emminger notes that "the transition to floating in the spring of 1973 marks exactly the point in time when the anti-inflation policy in Germany began to bite and when the German rate of price increase broke away from the general international inflation convoy." ${ }^{26} \mathrm{An}$ analysis of empirical evidence on movements in exchange rates and prices leads Kemp to conclude that "when the exchange rates had the greatest amount of freedom to respond to changes in fundamental factors, their observed movements paralleled relative inflation and money growth rates most closely. The results . . . thus lend support to the hypothesis that movements in exchange rates, particularly in the long run, are determined by relative inflationary pressures and relative rates of money growth." ${ }^{27}$

A concept in which exchange-rate movements offset divergent price trends implicitly takes domestic inflation rates as the causal force in the

26. Otmar Emminger, On the Way to a New International Monetary Order (American Enterprise Institute, 1976), p. 8.

27. Donald S. Kemp, "The U.S. Dollar in International Markets: Mid-1970 to Mid-1976," Federal Reserve Bank of St. Louis, Review, vol. 58 (August 1976), p. 13. 
movement of the exchange rate; and it ignores, or at least deemphasizes, the causation that runs from exchange rates to domestic inflation. But this latter causal process aggravates the problems of soft-money countries and lightens the burden of hard-money countries. This "vicious and virtuous circle" has been recognized by the Organisation for Economic Cooperation and Development and the Bank for International Settlements. ${ }^{28}$

In the short-run perspective appropriate for macroeconomic questions, exchange-rate movements can be viewed as a source of inflationary pressure. Depreciation, particularly in medium-sized and small countries, has a strong, direct impact on inflation of wholesale and consumer prices. The main channels are (a) costs of imported materials, (b) wages, (c) import prices of finished goods, (d) aggregate demand, and (e) a direct spillover into prices of import-competing goods.

The most important channel may be the direct effect of material costs on domestic costs and prices. By raising the domestic-currency prices of imported materials a depreciation will bring about higher costs which will be passed on directly into higher domestic prices. That process can operate very fast and essentially without regard to the unemployment rate. Unlike wage pressure that builds up as a consequence of sustained high demand, material prices can rise simply because a decline in interest rates forces a depreciation of the currency. The point is particularly important for the conduct of monetary policy because it implies that a monetary expansion translates into inflation much faster and with much less impact on real demand than it would in the absence of depreciation.

The inflationary impact of depreciation on wages depends largely on the weight of imports in the cost of living. In countries that depend heavily on imported food, such as Britain, the effect is important. ${ }^{29}$ Nevertheless,

28. See Bank for International Settlements, Forty-Sixth Annual Report, 1st April 1975-31st March 1976, pp. 30-32; Paul Lewis, "The Weak Get Weaker With Floating Rates," New York Times (October 10, 1976); and David King, "The Performance of Exchange Rates in the Recent Period of Floating: Exchange Rates and Relative Rates of Inflation" (Federal Reserve Bank of New York, May 1976; processed).

29. See Morris Goldstein, "The Effect of Exchange Rate Changes on Wages and Prices in the United Kingdom: An Empirical Study," International Monetary Fund, Staff Papers, vol. 21 (November 1974), pp. 694-739; George L. Perry, "Determinants of Wage Inflation around the World," BPEA, 2:1975, pp. 403-35; and the theoretical analysis in Michael Bruno, "Wage and Price Dynamics in the Open Economy" (Hebrew University, 1976; processed). The impact of depreciation on inflation in the United States has been studied by William Nordhaus and John 
in the context of short-run movements in exchange rates, it is perhaps not very important because it is a time-consuming process for the impact of exchange rates on the cost of living to be reflected ultimately in wages. ${ }^{30}$

In a different perspective, the relation between exchange rates and wages is all-important. Any expectation that a current depreciation will be sustained and raise prices will influence current wage settlements and, therefore, affect inflation. Clearly, in this context the U.K. wage stabilization program in mid-1976 was critical and entirely appropriate.

Exchange rates also affect the domestic price level via aggregate demand, as imports give way to domestic goods and exports expand. Since the real adjustment to price changes is slow, and since most of the impact on domestic prices will come through induced changes in employment and wages, this process works with considerable lag; and in the short run the impact may be much smaller than that operating through material prices and through the direct increase in prices of imported finished goods and food.

Table 3 presents reduced-form equations for the impact of import prices on the inflation process. The table shows selected equations that explain inflation in consumer prices in terms of its own lagged rate, activity variables, and inflation in import prices. ${ }^{31}$ Clearly, inflation in import prices contributes much to inflation in consumer prices. The coefficients for most countries are both sizable and precisely estimated. In particular, the coefficient of 0.14 for the United States exceeds the ratio of total imports to consumption, which is 0.12 . Similarly, for other countries except Germany, import prices have a strong impact on consumer prices. ${ }^{32}$

Shoven, "Inflation 1973: The Year of Infamy," Challenge, vol. 17 (May-June 1974), pp. 14-22; and Richard Berner and others, "International Sources of Domestic Inflation," paper 3, in Studies in Price Stability and Economic Growth, Prepared for the Joint Economic Committee, 94:1 (GPO, 1975).

30. There is some question whether the proper inflation variable in the wage equation is consumer price inflation or inflation of value-added prices. On the empirical evidence see Perry, "Determinants of Wage Inflation around the World."

31. On the role of import prices in domestic inflation see, too, Franco Modigliani and Lucas Papademos, "Targets for Monetary Policy in the Coming Year," BPEA, 1:1975, pp. 141-63; and Sung Y. Kwack, "Price Linkages in an Interdependent World Economy: Price Responses to Exchange Rate and Activity Changes," in National Bureau of Economic Research, Price Behavior, 1965-1974, forthcoming.

32. The extremely small coefficient for Germany is puzzling-the more so because the appreciation of the mark is believed to have dampened inflationary pressure in Germany. Part of the explanation is likely to come from the automatic adjustment of agricultural prices in response to exchange-rate movements. 


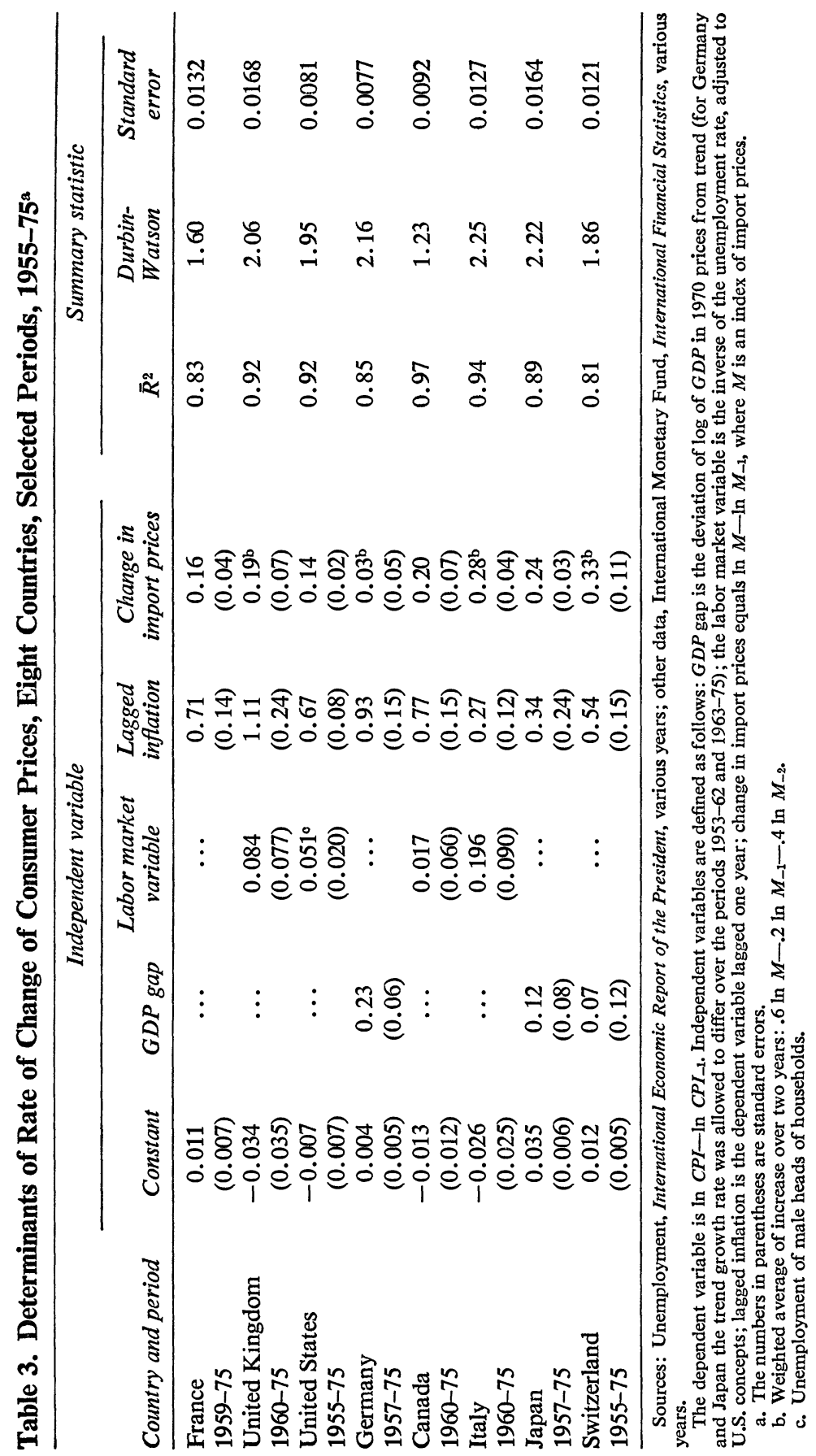


The link between exchange-rate deterioration and domestic inflation takes on importance in the context of our earlier argument that an expansionary monetary policy leads to a fall in the exchange rate. The present line of argument establishes a direct, short-run link between monetary policy and inflation. The conventional case for stabilization policy, including monetary policy - that it acts promptly on quantities and only slowly on prices-is, therefore, lost.

The argument is illustrated in the diagram below. The schedule $P P$ is the conventional flat short-run Phillips curve that relates the rate of change of value-added prices-say, the GNP deflator-to the level of unemployment. The argument for monetary policy is that the Phillips curve is flat, that wage pressure is slow to build up to an expansion in aggregate demand, and that, accordingly, there is an advantageous tradeoff between inflation and unemployment in the short run, from, say, $A^{0}$ to $A^{\prime}$. But an attempt to expand the economy through monetary policy in this manner will immediately cause the exchange rate to fall (or to

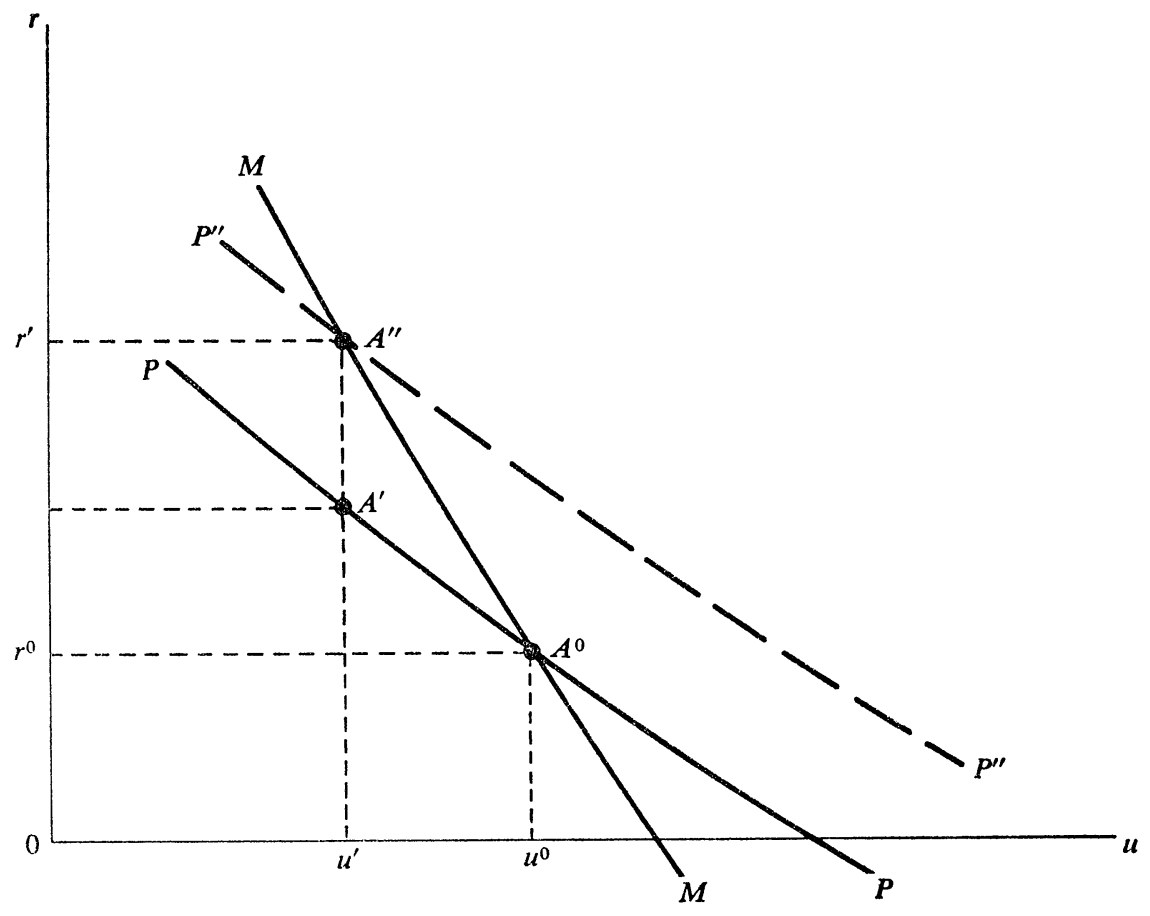


fall faster), thus raising domestic prices of imports and hence causing consumer and wholesale prices to rise at a higher rate. In terms of the diagram, the schedule $P^{\prime \prime} P^{\prime \prime}$ embodies the inflation arising from domestic wage pressure and from the impact of depreciation on import prices. It thus represents inflation of market prices rather than value-added prices. In terms of market prices an attempt to reduce unemployment from $u^{0}$ to $u^{\prime}$ will raise inflation to a greater extent, as shown by point $A^{\prime \prime}$.

The short-run Phillips curve in terms of market prices is $M M$ and is clearly much steeper than the conventional Phillips curve, quite apart from expectational adjustments. If, in addition, wage settlements are significantly affected by exchange-rate developments, that steepening effect is further intensified. ${ }^{33}$

\section{Summary and Policy Conclusions}

This paper has laid out a theory of the role of exchange rates in a short-run macroeconomic context. There are five key building blocks: (1) a relationship between interest rates and exchange rates, including exchange-rate expectations; (2) a relationship between exchange rates and relative prices, such that in the short run a currency depreciation (appreciation) raises (lowers) the relative price of imports; (3) a response of trade flows to relative prices, but with a lag measured in terms of years; (4) a significant impact of import prices on consumer prices, even in the short run, which implies that a currency depreciation of, say, 5 percent would raise consumer prices by between 0.5 and 1 percent, depending on the response of import prices to the exchange rate; (5) a response of export prices to competitors' prices, but one that is limited in the short run by the stickiness in export prices.

The major implication of these relations for short-run macroeconomic policy in an open economy is that the Phillips curve is much steeper when monetary policy is used for expansion. Indeed, the central message of the empirical results is that prices will rise promptly in response to a monetary expansion but that the real effects may even be dampened or perverse. The J-curve in the short run implies that a depreciation induced by mon-

33. Of course, the price adjustment in response to a monetary increase is a onceand-for-all increase in the level of prices, not a sustained inflationary process. It is nevertheless useful to cast the issue in terms of Phillips curves because the price increase will appear in the measured inflation rate over any particular time period related to the horizon of policymaking. 
etary expansion may actually lower the real demand for domestic output. In these circumstances monetary expansion may actually lead to more inflation and more unemployment.

A first presumption then is that countries should use a monetary-fiscal policy mix, applying fiscal expansion to stimulate aggregate demand and an accommodating monetary policy to maintain the rate of interest and therefore exchange rates. ${ }^{34}$

A second implication derives from the significant impact of exchange rates on import prices and of import prices on domestic prices. Given the influence of exchange-rate movements on domestic prices, a country would want to intervene to offset exogenous disturbances of exchange rates. Exchange-rate movements can disrupt price performance just as commodity inflation due to, say, harvest failures can. The argument that inventories of commodities should be established and used to counter inflation in the face of commodity shocks has a precise analog with respect to exchange rates. ${ }^{35}$ In the face of exogenous disturbances to exchange rates, governments should peg the rate and thus prevent the inflationary impact from being built into commodity prices, wages, and costs. This obviously assumes inventories of foreign currencies or the ability to borrow.

A third conclusion concerns policy in countries that may not be able to finance the external deficit that a monetary-fiscal policy expansion entails. In the absence of private capital flows, the current-account deficit arising from the expansion will sharply depreciate the currency. In the absence of reserves, or an ability of the private sector to borrow in the world market, public borrowing becomes appropriate.

The framework suggests that during a world recession a synchronized expansion is appropriate. Small countries cannot expand by themselves because they may lack the reserves or borrowing ability with which to maintain exchange rates. Unless large countries are willing to lend pub-

34. A similar argument has been made by Robert A. Mundell, The Dollar and the Policy Mix, 1971, Essays in International Finance 85 (Princeton University, International Finance Section, 1971).

35. The case for supply management through commodity inventories has been argued by Okun, "Inflation: Its Mechanics and Welfare Costs," pp. 387-88; George L. Perry, "Stabilization Policy and Inflation," in Henry Owen and Charles L. Schultze, eds., Setting National Priorities: The Next Ten Years (Brookings Institution, 1976), pp. 316-18; and Richard N. Cooper and Robert Z. Lawrence, "The 1972-75 Commodity Boom," BPEA, 3:1975, pp. 671-715. 
licly and thus finance their expansion, smaller countries confront a particularly disadvantageous tradeoff between inflation and unemployment. Not only would an expansion intensify inflation, but the induced depreciation would worsen the terms of trade and thus lower the real income of those already employed.

In contrast, a world expansion in aggregate demand would allow recovery of employment at constant exchange rates and therefore avoid the uncertainty associated with the J-curve and the potentially inflationary impact of exchange-rate movements. In the current recession, large countries have espoused hard-money philosophies and have favored a very moderate recovery. They have benefited in the foreign-exchange market by appreciation and an imported dampening of inflation. Soft-money countries, by contrast, have experienced the corresponding depreciation and thus have "imported" inflation. The virtuous and vicious circle has operated against expansionary countries. With renewed concern about world aggregate demand and with ongoing concern about high-inflation countries, a look at coordinated expansion in the world economy is in order. 


\section{Comments and Discussion}

Richard N. Cooper: This paper is an extremely useful synthesis of several strands of analytical thought. It integrates the new emphasis on asset pricing and expectations formation in the exchange market with the old emphasis on relative-price effects and movements in aggregate output and expenditure, or absorption.

As such, I think it represents a very useful corrective to new and important lines of thinking that otherwise would neglect the older and equally valid analysis in the short-term time frame. That horizon, on which Dornbusch and Krugman focus in their paper, is the relevant one for macroeconomic stabilization policy.

The second half of the paper does some relatively primitive empirical tests and finds that for large industrial countries (1) a change in the exchange rate affects the terms of trade; (2) a change in the terms of trade and hence the exchange rate affects trade flows, but only with a lag; (3) a change in the terms of trade is affected by-in effect, moderated by-the pricing of competitors for all countries except the United States; and (4) a change in the exchange rate affects domestic prices directly, without going through the goods market. Since all of these empirical results were consistent with my priors, following a time-honored practice in economics I did not look at the nature of the tests too closely.

I thought it would be useful, though, to introduce into the discussion some other empirical results found by Ronald McKinnon, by Robert Aliber, and by Stanley Black, which, via a somewhat different route, arrive at conclusions for macroeconomic policy that are very similar to those of Dornbusch and Krugman. The other results attempt to contrast the experience under relatively fixed exchange rates before March 1973, with the relatively flexible rates since 1973 . 
We have now had about three years of experience with flexible rates, and can begin to ask how the two regimes compare. The first, and again not entirely surprising, empirical result is that bid-ask spreads on exchange rates-the difference between the buying and selling price-widened, by a factor of five to ten, after March 1973.

Second, the forward exchange rates do a very poor job of forecasting spot rates, and they do a worse job under flexible rates than they did under fixed rates. Under flexible rates they have been strongly biased as well as inaccurate estimators. This means that there have been substantial unexploited possibilities for speculative profit.

Third, exchange-rate movements have done a poor job in the short run -by which I mean four to six quarters-of tracking purchasing power parity between countries. Again this has been worse in the last three years than before that.

The sharp fall in the pound in 1976, for example, although surprising to journalists, should not have surprised anyone who had looked at relative-price-wage comparisons. What was surprising was that the value of the pound stayed as high as it did in 1973 and 1974 in the face of the large inflation differential between Britain and other industrial countries.

These empirical results suggest that expectations about exchange rates are quite shallow, and are easily moved by relatively ephemeral events. Very short-run perceived or actual changes in monetary policies exert considerable influence on the exchange rate.

As Germany and the United States are far and away the biggest trading countries, and the mark has now surpassed the pound as an international currency, the mark-dollar rate now represents the key exchange rate in the world. This exchange rate has moved up and down by roughly 10 to 15 percent every six months and has shown virtually no trend for the last three years. There is something to the argument that the markets have not really adjusted yet to the new situation. But I think that that process would and should be helped to some extent if the central banks were more active in exchange-market intervention than they have been.

By intervening to stabilize movements in exchange rates, the central banks could actually earn profits, but that is incidental. The main purpose is to smooth short-run movements without at the same time resisting longer-run trends which are, and should be, roughly parallel to movements in purchasing power parity. This is confirmed by the main DornbuschKrugman conclusion for policy: that an active component of macroeco- 
nomic policy should be exchange-market intervention-which is another form of monetary policy - to neutralize any random disturbances from the exchange rate.

Let me conclude by taking up the paper's argument that the short-run Phillips curve (loosely interpreted to encompass changes in price levels as well as rates of inflation) associated with changes in monetary policy is a lot steeper with flexible exchange rates than it would be with fixed exchange rates. Obviously, the more open the economy the more force this point has. That section of the paper perhaps suggests an implicit comparison with a fixed-exchange-rate regime in which open economies have less difficulty with macroeconomic management. But extremely open economies have troubles with macroeconomic management under either fixed or flexible rates. As the authors suggest, flexible rates worsen the Phillips tradeoff; but with a fixed exchange rate, monetary policy does not work at all because a dollar's worth of monetary expansion simply escapes to the rest of the world and is undone through exchange-market intervention by the central bank.

Even fiscal policy has only a small leverage on domestic demand if the marginal propensity to import is very high. The case that Dornbusch and Krugman make for coordinated macroeconomic policy under flexible rates applies as well for small countries on fixed rates. They are much better off if they move together than if they act independently. A really open economy is open under fixed as well as flexible rates.

Marina v. N. Whitman: This paper is eclectic in the best sense of the word. Three approaches to the analysis of balance-of-payments and exchangerate adjustments - the asset-market, the Keynesian, and the purchasingpower models-which were formerly viewed as competing explanations, have been synthesized into a composite theory that comes closer to explaining real-world phenomena than any one of its components.

Basically, Dornbusch and Krugman show that the asset-market approach, which stresses the role of portfolio-balance and stock adjustments in exchange-rate determination, yields the same result as the traditional Keynesian model when the latter incorporates capital mobility (as in the Mundell-Fleming version) as well as expectations, and downplays the role of current-account adjustments in the short run.

The authors' eclectic theoretical structure has several implications that 
are consistent with common sense, but that seem to be denied by the simpler versions of theoretical formulations that have enjoyed considerable currency lately: (1) that, in a world of capital mobility, flexible exchange rates do not provide full insulation, even from purely monetary disturbances; and (2) that there is nothing surprising about short-run fluctuations in exchange rates that are much larger than appear to be warranted by price-cost divergences among countries but that are induced by changes in interest-rate differentials.

The empirical evidence presented by Dornbusch and Krugman has three basic implications. First, it gives considerable support to the Keynesian notion that exchange rates affect relative prices, or the terms of trade, over a considerable period. Second, relative prices do affect trade flows, although the lags involved are long. Third, along with this confirmation of Keynesian conventional wisdom, however, they caution us (implicitly if not explicitly) against overgeneralization. Different countries seem to have had different experiences. On the one hand, in the United States and Japan, changes in exchange rates were paralleled by changes in competitiveness, lending support to the Keynesian view. On the other, in the United Kingdom and Germany, exchange-rate changes had very little effect on competitiveness because they were offset by relative movements in domestic rates of inflation, thus supporting the monetarist view.

I found one thing missing from the empirical work in this paper: an examination of the shift between imports and import substitutes when the terms of trade change. A theory that focuses on relative-price changes predicts quantity shifts on both the export and the import sides in response to changes in the terms of trade. But the empirical evidence in the paper is limited to exports or, more precisely, export shares.

The analysis has, I think, one general problem. It created some confusion - on the part of the reader if not on the part of the authors-about the length of the period under discussion. The authors characterize the whole paper as short-run analysis, but several different lengths of run are actually involved in their composite adjustment process. Their scheme implies that, when some disturbance affects the exchange market in the short run, asset markets adjust immediately. The resulting change in the exchange rate produces a change in relative prices or the terms of trade. This subsequently causes a change in the current account, which is the mirror image of the change in the capital account, in the medium run 
(something like two to three years). And then, presumably, some interaction between the exchange rate and the domestic price level restores purchasing power parity in the long run.

But I am a little uncertain about that last step. The interactions the authors discuss are really quite short run, and it seems to me that the weakest theoretical link in the paper is from the Keynesian medium run to long-run purchasing power parity. Presumably, that adjustment involves more than the one-way effect of exchange rates on domestic prices, which is covered in the paper. The reverse effects of price levels or inflation rates on the exchange rate must enter into the process for the long run.

The analysis leads to interesting policy conclusions. But it is striking that, at least in one respect, the fundamentally Keynesian reasoning leads to a supermonetarist conclusion - that, in open economies, monetary policy is ineffective in altering the level of real economic activity, even in the short run.

The authors pose two major policy dilemmas. One is that exchangerate fluctuations that are excessive in relation to real divergences in price levels-reflecting the more rapid adjustment of asset markets and slower adjustment of the current account-have a negative impact on economic welfare.

One solution is direct intervention in the exchange markets. The authors draw an analogy to the use of buffer stocks to dampen fluctuations in commodity markets. But, as in the case of buffer stocks, exchange-rate intervention should be symmetrical with respect to overshooting and undershooting. Yet the authors seem to argue asymmetrically: they urge countries to intervene to prevent the exchange rate from rising (the currency from depreciating) excessively in the short run, but they don't prescribe for exchange rates that fall unduly in the short run. If buffer stocks are not managed symmetrically, they will either become massive or run out, and there are analogous problems in exchange-rate management-as the old fixed-rate system demonstrated.

A second solution to excessive fluctuations of exchange rates invokes Mundell's policy-mix prescription that directs fiscal policy toward domestic stabilization and monetary policy toward exchange-rate constancy. The problem here is that the little bit of empirical evidence I have seen shows no simple correlation at all between interest rates and exchange 
rates. The relationship depends on the nature of the disturbance: if a rise in interest rates is due to tight money, it will be associated with appreciation of the currency; but if it is due to a boom and a rise in inflationary expectations, it will be associated with a depreciation. Furthermore, the analysis allows for no responsiveness of capital flows to real income growth. I believe that is an important phenomenon in the real world and I wonder how it would alter the policy conclusions.

Finally, as a third possible solution, the authors suggest policy coordination. That is something we can all support, but it is discussed only by example and not defined rigorously.

The second big policy dilemma the authors pose is the so-called "vicious and virtuous circle" - that is, the notion of improving Phillips curves in countries that initially have an inflation performance better than the average, and worsening Phillips curves in countries that initially have an especially unfavorable tradeoff.

This problem begins to push us back into the world of the disequilibrium system that Mundell described under fixed rates, and that we thought we were escaping by moving to flexible rates. The authors might, with some justification, argue that this is a long-run problem and therefore outside the purview of this paper. But the possibility remains that the operation of the exchange-rate mechanism they describe for the short run might create dynamic instability in the long run. Hence this very useful and very informative paper leaves me at the end with a lingering sense of unease.

\section{General Discussion}

Franco Modigliani said that the most important mechanism brought out by the paper was the way monetary expansion would alter the price level via changes in the exchange rate. He felt that exchange-rate movements due to interest-rate differentials ought to be short-lived and to be reflected more in spot than in forward rates. To the extent that these effects are perceived as temporary, the prices of imported goods ought not to move much. Modigliani observed, however, that if speculators did not behave to dampen these changes, a destabilizing process would afflict the system. He pointed to the recent debate on the appropriate policy for Italy, in which some analysts have argued that that country cannot afford 
to devalue because it does not have sufficient reserves to handle the J-curve effects. This reasoning implies that speculators do not perform their required role.

Dornbusch and Krugman expanded on Cooper's remark that expectations have been extremely volatile and that the forward rate under flexible exchange rates has been both a poor and a biased predictor of future rates. William Poole queried Krugman skeptically on the nature and conclusiveness of the statistical tests that had yielded those findings. Dornbusch added that the evidence on the relationship between interest-rate differentials and exchange-rate changes was mixed, for the reasons Marina Whitman had pointed out: exchange-rate changes between the United States and Germany were correlated with their interest-rate changes; those between the United States and the United Kingdom were not.

Several participants were troubled by the paper's treatment of the distinction between exogenous and endogenous variables. Poole pointed out that at times the exchange rate was spoken of as exogenous; at other times, as was more appropriate under flexible rates, it was treated as an endogenous variable. Poole felt that it was wrong to refer to an exchange-rate change as exogenous without describing the prior disturbance that had caused the change- a point, he noted, that Whitman had made with respect to interest rates. Others identified similar problems in the interpretation of the equations: Stephen Marston noted that the chain of causation might run from inflation via a depreciation into import prices and not vice versa (and that this might explain the large U.S. coefficient). George Perry suggested that the effect of import prices on consumer prices in table 3 would be understated if they influenced wages and hence standard unit labor costs of exported products and import substitutes. Christopher Sims pointed out that aggregate demand could influence import prices and suggested that tests for exogeneity might be undertaken. In response, Dornbusch agreed that one had to be very careful in saying why the exchange rate moved, but stressed that, in the short run, exchange rates are far more volatile than the inflation rate and have an impact independent of it. Paul Krugman said that the failure of exchange rates in the short run to follow purchasing power parity, and the fact that much of the change in import prices was due to the commodity boom and the increase in oil prices, provided the rationale for considering import prices as predetermined.

Walter Salant pointed out that import prices might also affect the price level through the direct impact on import-competing goods. He felt that 
this might explain the large coefficient on imports in the U.S. price equation. Dornbusch doubted that this could be an inflationary force without an increase in aggregate demand. Salant replied that such demand might be "prospective" and Cooper cited some mixed evidence on the effects of U.S. tariff increases: in some cases, domestic producers competing with imports marked up their prices immediately; in other cases they did not. Concurring with Sims, Modigliani observed that demand in the United States might influence import prices. He also distinguished between the effects of an increase in the price of an imported commodity that might occur because prices of a domestic substitute rose, and the larger impact of a devaluation that raised the prices of both imports and import-competing goods. It was this latter effect that the authors had appropriately captured in their regressions.

Salant felt that too much reliance had been placed upon terms-of-trade effects. Devaluation, he pointed out, can work without changing the terms of trade by inducing increased supplies of tradables because their prices rise in domestic currency or by changing the relative price of traded and nontraded goods or both.

Salant questioned the use of bilateral weights in calculating effective exchange rates because these are inaccurate indicators of competitive positions in third markets. The yen would not be given much weight in the effective exchange rate of the mark because there is not much trade between Germany and Japan. But this might be misleading insofar as both countries compete in other markets-for example, the U.S. automobile market. William Fellner observed that what was really required was a model that determined the weights endogenously, but Krugman and Dornbusch noted that they had tried a variety of techniques for weighting export shares and found the results very insensitive to the choice among weighting procedures.

Marston asked whether it was appropriate to introduce the once-andfor-all inflationary impact of a depreciation into the Phillips curve. Dornbusch agreed that a depreciation might have a once-and-for-all effect, but pointed out that it might well enter into wages and produce a continuing inflation. Edmund Phelps was also puzzled by the use of the Phillips curve in this context: when the curve is viewed as a structural relation between the rate of change of prices and unemployment, why should its shape depend on the origin of changes in demand? Dornbusch replied that, for an open economy, even if the relationship between the unemployment rate 
and the GNP deflator is independent of the sources of demand, that involving the consumer price index would not be independent since it reflected import prices and hence the exchange rate. Whitman noted that even if the government kept aggregate demand constant, the consumer price index would rise if prices of imported goods rose.

The issues raised in the paper about international policy coordination also evoked several comments. Marston was not convinced of the necessity for coordinated expansion among countries. It seemed quite possible to him that, knowing what fiscal-monetary strategies the others were pursuing, each country might have sufficient instruments to pick a policy mix that would achieve its own targets independently. In that sense, the international problem was exchanging full information about independent actions rather than coordinating the actions. Charles Holt asked about the adequacy of current professional knowledge to achieve international coordination, assuming the countries wanted to coordinate. Dornbusch confirmed Holt's suspicions that the quantitative bases of knowledge were weak. If the questions were the effect on the growth rate of West Germany from adding one point to the growth rate of the United States, Dornbusch knew of two models that would give answers that differ by a factor of ten. He insisted, nonetheless, that knowledge about directions and rough orders of magnitude was sufficient to support preferences for some policy mixes among countries over others.

Fellner noted that any coordination among countries required some decision on whether the major emphasis was for the less inflationary countries to expand more or for the more inflationary countries to expand less. That decision seemed particularly critical in view of the Dornbusch-Krugman lesson that exceptionally inflationary countries cannot take care of their international problem simply by allowing their exchange rates to fall. 